PONTIFÍCIA UNIVERSIDADE CATÓLICA do RIO dE JANEIRO

\title{
ASSÉDIO MORAL NO AMBIENTE DE TRABALHO: UM ESTUDO ENVOLVENDO EMPRESAS PRIVADAS
}

Manoella Gomes Linhares

Trabalho de Conclusão de Curso

Centro de CiÊnCIAS Socials - CCS

DEPARTAMENTO DE AdMINISTRAÇÃo

Graduação em Administração de Empresas

Rio de Janeiro, junho de 2019. 


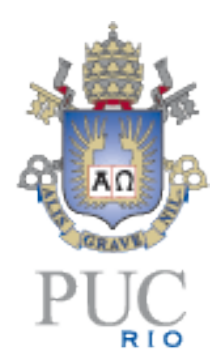

Manoella Gomes Linhares

\section{Assédio Moral no ambiente de trabalho: Um estudo envolvendo empresas privadas}

Trabalho de Conclusão de Curso

Trabalho de Conclusão de Curso, apresentado ao programa de graduação em Administração da PUC-Rio como requisito parcial para a obtenção do título de graduação em Administração.

Orientador: Renata Kurtz 
"O que me preocupa não é nem o grito dos corruptos, dos violentos, dos desonestos, dos sem caráter, dos sem ética. O que me preocupa é o silêncio dos bons."

Martin Luther King 


\section{Agradecimentos}

Primeiramente aos meus pais que com todo sacrifício me ajudaram a dar continuidade aos meus estudos. Principalmente à luz da minha vida, minha mãe, Izabel Gomes, que, além de se desdobrar para ver o meu sucesso, sempre ofereceu todo apoio em termos emocionais.

Aos meus amigos de infância: Dimayma Nascimento, Leonardo Dantas, Paula Machado, Pedro Paulo dos Santos e Tainá Aguiar. Obrigada por vivenciarem os momentos mais marcantes durante a minha vida e por todo apoio.

À PUC-Rio, que me proporcionou tanto conhecimento e me fez conhecer pessoas incríveis que aguentaram diversos episódios comigo nesses cinco anos de crescimento. Em especial à Ana Carolina Sousa, André Regis, Francisco José Martins, Giuliana Mota, Henrique Rangel, Nathalia Barbieri, Pedro Renato Rodrigues, Ricardo Oliveira, Roberta Veloso, Sharon Paskin e William de Assis. Não poderia esquecer de Raphael Barbosa, um anjo em minha vida que me segurou nos piores momentos.

Aos meus queridos professores de escola e de faculdade que contribuíram com meu crescimento pessoal, acadêmico e profissional. Em específico à Alessandra Baiocchi, Andrea Cherman, André Roizman, Bárbara Levy, Carlos Alex Sanches, Lygia Magacho, Marcela Amorim, Mila Desouzart Viana, Patrícia Ítala, Raquel Fonteneles, Regina Moreira, Roberto Gil Uchoa e Roseli Schaefer.

À Patrícia Coralis que me fez expandir meus horizontes, proporcionando uma visão de mundo que jamais iria obter sozinha.

À minha orientadora, Renata Kurtz, minha professora e amiga do coração, que aceitou mergulhar nessa aventura com suas ideias e incentivos.

À todos que me acompanharam ao longo da minha vida. 


\section{Resumo}

Linhares, Manoella G. Kurtz, Renata G. M. Assédio moral no ambiente de trabalho: um estudo envolvendo empresas privadas. Rio de Janeiro, 2019. Número de páginas: 41. Trabalho de Conclusão de Curso - Departamento de Administração. Pontifícia Universidade Católica do Rio de Janeiro.

O atual estudo buscou analisar o fenômeno presente no ambiente de trabalho, composto por sessões habituais de humilhação, constrangimento, ofensa e depreciação de colaboradores. Também conhecido como assédio moral, o evento promove insegurança, estresse e impactos físicos, mentais e comportamentais. Para compreendê-lo melhor, buscou-se levantar através da pesquisa qualitativa, com caráter descritivo, a vivência do assédio moral pelos trabalhares de níveis operacionais e estagiários de empresas privadas do Estado do Rio de Janeiro, com um período mínimo de três meses de ocorrência durante os últimos seis anos, assim como as consequências para a saúde dos afetados. Como conclusão, foi possível verificar que grande parte dos entrevistados se depararam com o evento. Suas experiências evidenciaram e confirmaram os mecanismos utilizados pelos assediadores no que diz respeito às atitudes hostis e, em todos os casos, houve pelo menos uma consequência física, comportamental e/ou psicológica. Ademais, torna-se evidente a necessidade de maior discussão acerca do tema, a fim de conscientizar as empresas e seus colaboradores deste evento.

Palavras-chave

Assédio moral no trabalho; Consequências na saúde; Nível operacional; Estagiários 


\section{Abstract}

Linhares, Manoella G. Kurtz, Renata G. M. Moral harassment at work: a study involving private companies. Rio de Janeiro, 2019. Number of pages: 41. Term paper - Business department. Pontifícia Universidade Católica do Rio de Janeiro.

The present study sought to analyze the phenomenon present in the workplace, composed of habitual sessions of humiliation, embarrassment, offense and depreciation of employees. Also known as moral harassment, the event promotes insecurity, stress, and physical, mental, and behavioral impacts. In order to understand it better, it was sought to raise through qualitative research, with a descriptive character, the experience of moral harassment by the workers at operational levels and interns of private companies in the State of Rio de Janeiro, with a minimum period of three months of occurrence during the last six years, as well as the health consequences for those affected. As a conclusion, it becomes clear that there is a need for greater discussion about the theme, in order to raise the awareness of companies and its employees of this event. As a conclusion, it was possible to verify that a large number of the interviewees came across the event. Their experiences revealed and confirmed the mechanisms used by the harassers regarding hostile attitudes, and in all cases, there was at least one physical, behavioral and / or psychological consequence. In addition, it becomes evident the need for greater discussion about the subject, in order to make the companies and their collaborators aware of this event.

Keywords

Moral harassment at work; Health consequences; Operational level; Interns 


\section{Sumário}

1. Introdução 1

1.1. Objetivo final 2

1.2. Objetivos intermediários 2

1.3. Delimitação do estudo 3

1.4. Relevância do estudo 3

2. Referencial Teórico 4

2.1. Breve histórico 4

2.2. Definição do assédio moral 6

2.3. Assédio moral, danos morais e conflitos 9

2.4. Diferenciações entre assédio moral e sexual 11

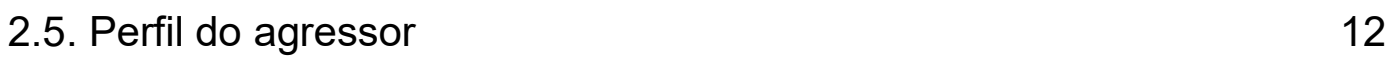

2.6. Perfil da vítima 13

$\begin{array}{ll}\text { 2.7. Causas e consequências } & 13\end{array}$

3. Metodologia 15

3.1. Processo da análise e interpretação dos dados 15

$\begin{array}{ll}\text { 3.2. Tipo de Pesquisa } & 15\end{array}$

3.3. Procedimentos e instrumentos de coleta de dados utilizados no $\begin{array}{ll}\text { estudo } & 16\end{array}$

3.4. Fontes de informação selecionadas para coleta de dados no estudo16

3.5. Formas de tratamento e análise dos dados coletados para o estudo18

$\begin{array}{ll}\text { 3.6. Limitações do método } & 18\end{array}$

4. Apresentação e Análise dos Resultados 20

4.1. Categorização do assédio moral 20

4.2. Categoria 1 - Atitude hostil 20

4.2.1. Subcategoria 1: Deterioração proposital das condições de trabalho20

4.2.2. Subcategoria 2: Isolamento e recusa de comunicação 23

4.2.3. Subcategoria 3: Atentados contra a dignidade 24

4.2.4. Subcategoria 4: Violência verbal, física ou sexual 26

4.3. Categoria 2 - Abuso de poder 28 
4.4. Consequências do assédio moral

5. Considerações Finais

6. Referências Bibliográficas

7. Anexo

7.1. Roteiro da Entrevista 


\section{Índice de ilustrações}

\section{Figura}

Figura 1: Processo de análise e interpretação dos dados 15

\section{Quadros}

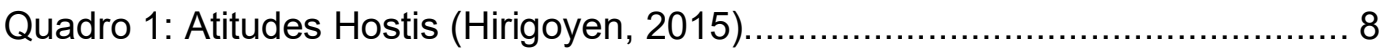

Quadro 2: Diferenças entre Conflito e Assédio Moral ....................................... 11

Quadro 3: Consequências do Assédio Moral................................................ 14

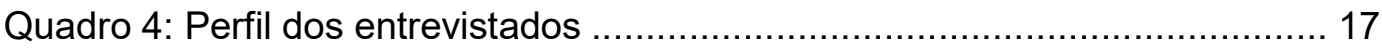

Quadro 5: Deterioração proposital das condições de trabalho ......................... 21

Quadro 6: Isolamento e recusa de comunicação........................................... 23

Quadro 7: Atentados contra a dignidade ................................................ 25

Quadro 8: Violência verbal, física ou sexual ................................................. 27

Quadro 9: Subcategorias emergidas do campo.......................................... 29

Quadro 10: Consequências do Assédio Moral............................................... 30 


\section{Introdução}

O advento do crescimento tecnológico, marcado especialmente pela Revolução Industrial no século XVIII, levou a uma redefinição da divisão do trabalho, impactando principalmente as formas de gerenciar, que passaram a visar predominantemente a qualidade e a produtividade (HELOANI, 2004). Com isso, houve uma exigência para os funcionários, além da qualificação necessária, em aprender e se adaptar a esta realidade, dando origem a um novo perfil profissional, o qual compreende alta capacidade de concentração, adaptabilidade, flexibilidade, raciocínio lógico rápido e agilidade no atendimento das demandas (ZIMMERMANN; SANTOS; LIMA, 2002).

No que tange aos gerentes, estes também foram impactados por mudanças. O novo perfil demandou o emprego dos valores competitivos e modelos adequados para a ocorrência dessa competitividade, estabelecimento de metas e cobrança dos subordinados pela produtividade, em detrimento da saúde e do relacionamento dos colaboradores (BARRETO, 2006). A junção destes tem como objetivo aumentar a lucratividade e diminuir os custos, a fim de maximizar o valor para a organização e, consequentemente, para os acionistas (FLEURY, 1989).

Para Barreto (2006), esses fatores transformaram os funcionários em utensílios, os quais são facilmente descartáveis e bastante alienados, ou seja, que não sabem pensar por si só. Em paralelo, Fabrício (2012) destaca que há o desestímulo à criação, à autonomia e o impedimento dos direitos básicos do ser humano, resultando em um "egocentrismo competitivo" que definha o caráter e que representa um prenúncio sutil para a violência no trabalho. Barreto (2006, p. 99) ilustra essa ideia no trecho a seguir:

"Homens e mulheres, feitos objetos da ganância e da negligência empresarial, adoecem, sofrem acidentes ou morrem suavemente no trabalho. Os trabalhadores que adoecem no trabalho são demitidos, aumentando o contingente de adoecidos e marginalizados, oriundos do processo produtivo dos bens de consumo." 
Esse contexto configura um terreno fértil ao surgimento do fenômeno do assédio moral, que segundo Barreto (2006) e Freitas (2007) ocorre quando comportamentos inapropriados se tornam parte do dia a dia sem consequências da organização pelos atos cometidos, por não possuir regras, autoridade ou filosofia que impeçam ou venham a puni-los. Além disso, Freitas (2007) destaca que as organizações com cultura e clima organizacional permissivos transformam o relacionamento entre colaboradores, tornando-o desrespeitoso e estimulando a conivência com o insulto e o abuso intencional.

Barifouse (2015) afirma que metade da população brasileira, cerca de $54 \%$, já sofreu assédio no trabalho, porém uma minoria denuncia. Ademais, $34 \%$ das pessoas entrevistadas disseram ter presenciado algum colega passando pela situação.

Diante do abordado, o presente estudo tem o intuito de responder à seguinte pergunta: Quais são as principais queixas relacionadas ao assédio moral e suas consequências geradas nos trabalhadores brasileiros?

A motivação da pesquisa se deu pelo fato da pouca atenção dada à temática, ao baixo nível de preocupação das organizações com o assunto (FIOCRUZ, 2014) e com o intuito de destacar os malefícios de quem sofre com os episódios.

\subsection{Objetivo final}

O objetivo final ao responder à pergunta problema foi de investigar as principais percepções de assédio moral e suas possíveis consequências que as vítimas identificaram sobre esse fenômeno.

\subsection{Objetivos intermediários}

Para atingir o objetivo final de investigar a percepção das vítimas sobre o problema desta pesquisa, foram formuladas questões norteadoras destacadas a seguir:

- Investigar como ocorreu o assédio moral;

- Investigar os mecanismos utilizados pelos assediadores;

- Investigar as possíveis consequências físicas, psicológicas e comportamentais. 


\subsection{Delimitação do estudo}

O estudo abordou o assédio moral à luz dos trabalhadores dos cargos operacionais e estagiários que vivenciaram esse fenômeno pelos superiores hierárquicos e pares nas empresas privadas localizadas no Estado do Rio de Janeiro, durante pelo menos três meses nos últimos seis anos. A abordagem foi analisada segundo a Lei 5.452/43 de 01 de maio de 1943, Art $^{\circ} 483$ (PLANALTO, 1943).

\subsection{Relevância do estudo}

No que tange à relevância do estudo, é possível abordá-la por meio de três pontos: acadêmico, social e profissional.

Em relação ao primeiro, pode-se destacar a contribuição com a área acadêmica, que embora esteja sensível ao assunto, dado o crescente número de pesquisas e artigos a respeito, ainda é carente sobre a problematização e as propostas de solução do problema (FIOCRUZ, 2014).

Já em relação à relevância social, o propósito é elucidar a definição correta, já que, segundo Hirigoyen (2015), nem todos os que dizem assediados foram de fato assediados, além de mostrar a gravidade do fenômeno e os impactos físicos, psicológicos e comportamentais no indivíduo, contribuindo para que a sociedade conheça mais sobre o assunto.

Por fim, a colaboração com a área profissional se dá pela exposição da importância dos gestores em se preocupar com seu comportamento no trabalho, gerando mais responsabilidade pelas consequências dos seus atos nas relações interpessoais. 


\section{Referencial Teórico}

\subsection{Breve histórico}

$\mathrm{Na}$ Antiguidade, já se tinha uma ligeira noção do que seria a divisão do trabalho. Os escravos realizavam a atividade manual exaustiva indigna aos cidadãos conhecida como "trabalho", enquanto que os homens livres dedicavam seu tempo à política, filosofia e viviam para as ideias, objetivando controlar o comportamento dos cidadãos da poli (BEZERRA e MARQUES, 2013).

$\mathrm{Na}$ época do feudalismo, na Idade Média, este conceito foi mudando de "castigo de Deus" para servidão, sendo uma forma do homem alcançar a ascensão ao reino dos céus. Nessa fase, não havia a exploração pura do homem para o homem como ocorria na escravidão, mas, ainda assim, a ideia de trabalho não era interpretada como algo positivo (CAVALCANTE e NETO, 2017). A associação deste com uma forma prazerosa de atividade foi concretizada pelos iluministas, por meio da disseminação do tripé "liberdade, igualdade e fraternidade". Isso resultou em uma mudança drástica, culminando na Revolução Francesa e na Primeira Revolução Industrial (BEZERRA e MARQUES, 2013).

O evento conhecido como Revolução Industrial foi marcado por mudanças sem precedentes da sociedade industrial, transformando o processo produtivo da manufatura para a maquinofatura e das relações de trabalho com a criação do proletariado, caracterizando, desta forma, uma nova divisão do trabalho (HOBSBAWM, 2014). O ambiente organizacional era descrito como desumano, com uma utilização excessiva da mão de obra, salários baixos, jornadas fatigantes e permuta do trabalho por comida. Em síntese, entende-se que houve a preferência do lucro ao invés do apreço pelas relações humanas (CAVALCANTE e NETO, 2017).

Nos dias atuais, percebem-se resquícios do contexto organizacional da Revolução Industrial, como a preferência do lucro e a crescente busca por resultados, fomentado principalmente pelos gestores, a fim de satisfazer os acionistas. Desta forma, o ambiente de trabalho pode se tornar instável devido aos riscos pessoais e profissionais, além de possibilitar oportunidades para a 
ocorrência do assédio moral (OLIVEIRA, 2004). Martins (2012, p. 33) demonstra o novo modus operandi da seguinte maneira:

"Diante da globalização, da automação, da competitividade dos produtos para poderem ser vendidos no mercado, o empregado está sujeito a produzir mais, com mais qualidade, a ser cobrado por metas, resultados etc. Em razão da maior tensão que passa a existir no ambiente de trabalho, surgem as doenças do trabalho e também o assédio moral."

Analisando de forma cronológica, o termo se originou no campo da Biologia por volta da década de 1960 por Konrad Lorenz. Este pesquisador identificou condutas hostis e intimidadoras, em específico o emprego de comportamentos agressivos e ameaças, de um grupo de animais que pretendiam espantar os invasores (FERREIRA, 2004).

Após isso, Peter-Paul Heinemann, em 1972, aproveitou o estudo anterior para analisar e compará-lo com comportamentos agressivos entre os grupos infantis. Ele relatou que os comportamentos eram semelhantes caso uma criança tivesse seu espaço invadido por outra. Com isso, foi feita a primeira publicação referente à expressão mobbing. O verbo, na língua inglesa, significa maltratar, perseguir, sitiar, atacar e o substantivo faz referência à turma e à multidão. Também é conhecido por bullying, harassment, psicoterror ou terrorismo psicológico (HIRIGOYEN, 2008).

No âmbito acadêmico, as pesquisas foram feitas pela primeira vez por Heinz Leymann em 1984, quando este divulgou um ensaio científico pelo National Board of Occupational Safety and Health, relatando os efeitos neuropsíquicos na vítima que passou pelas situações constrangedoras e humilhantes durante o expediente no trabalho (GUEDES, 2003).

No Brasil, a lei criada em 1988 pela Constituição da República Federativa do Brasil previu a sanção por danos morais em caso de ofensa aos direitos fundamentais do ser humano (FONSECA, 2003). O termo ganhou destaque com uma das primeiras publicações acerca do tema em uma dissertação da mestranda Margarida Barreto em 2000, intitulada de Uma jornada de Humilhações (HIRIGOYEN, 2015). Neste estudo, os entrevistados descrevem as desqualificações, constrangimentos e humilhação na jornada laboral. Somente após esse acontecimento, o tema passou a ser mais debatido nas mídias nacionais, como TV, jornais, revistas e internet (COSTA et al., 2015). 


\subsection{Definição do assédio moral}

Conforme Leymann (apud MENEZES, 2004, p. 191) retrata, o mobbing se caracteriza pela utilização de manipulações que geram terror psicológico e violam sistematicamente os direitos da vítima. Esta situação pode ocasionar a exclusão da pessoa do emprego e do mercado de trabalho devido ao desgaste psicológico, tornando-a incapaz de encontrar um novo emprego. Ademais, o assédio moral ocorre "como reação de um quadro de miséria física, psicológica e social duradoura" (LEYMANN, apud MENEZES, 2004, p. 191).

Em paralelo, Hirigoyen (2015) utiliza a definição de assédio moral para identificar mecanismos utilizados pelos assediadores como atitudes hostis caracterizadas por quaisquer comportamentos abusivos repetidos, evidentes por meios verbais ou não verbais, através de palavras, gestos, atos, escritos ou comportamentos, com o efeito de danificar a dignidade, personalidade ou integridade psíquica ou física de um ser, degradando seu ambiente organizacional ou até mesmo colocando em risco seu emprego.

Para Piñuel e Zabala (2003, p. 32), a intenção é de amedrontar, humilhar e desonrar o indivíduo, fazendo com que o intelecto e o emocional cheguem ao limite. O plano é claro: forçar a demissão do assediado ou de se obter prazer com os comportamentos de agressão, controle e destruição, aproveitando "a situação organizacional particular (reorganização, redução de custos, burocratização, mudanças drásticas etc.) para canalizar uma série de impulsos e tendências psicopáticas".

Como há diversas maneiras de conceituar o "assédio moral" devido às vastas formas de ocorrência (TORRETA e NÓBREGA, 2012), há termos comumente que podem ser destacados, como a violência por parte do assediador (BARROS, 2009), exposição e humilhação da vítima, com a finalidade de acabar com a sua autoestima, atrapalhar a sua reputação, integridade física ou psicológica por um tempo prolongado (FONSECA, 2007).

Para a Consolidação das Leis do Trabalho (CLT), o assédio moral se enquadra na Lei 5.452/43 de 01 de maio de 1943, Art $^{\circ} 483$ (PLANALTO, 1943). Conforme a referida Lei, o Ministério Público do Trabalho adverte que o assédio moral se configura quando ocorre: 
- Repetição prolongada e sistemática da situação abusiva;

- Intencionalidade de forçar o outro a renunciar ao emprego;

- Direcionalidade: uma pessoa do grupo é escolhida como bode expiatório;

- Temporalidade ou frequência dos casos: durante a jornada, por dias, meses ou anos;

- Destruição das condições de trabalho de forma proposital

A predominância da ocorrência, aproximadamente $90 \%$ dos casos segundo as pesquisas, é de assediadores em níveis hierárquicos superiores aos assediados, mas também há relatos de práticas por um conjunto de colegas ou pelo próprio subordinado para o superior (BARRETO, 2006).

Ainda para a psiquiatra Hirigoyen (2015), o assédio moral realiza-se por meio de mecanismos que refletem as atitudes hostis em quatro esferas de comportamento, dentre elas a proposital danificação das condições de trabalho; a exclusão e rejeição da conversa; a violação da dignidade; e a violência física, sexual ou verbal; todas expostas da mais sutil para a mais visível de acordo com o Quadro 1 abaixo: 
Quadro 1: Atitudes Hostis (Hirigoyen, 2015)

\begin{tabular}{|c|c|}
\hline Atitudes Hostis & Elemento de análise \\
\hline \multirow{17}{*}{$\begin{array}{l}\text { Deterioração } \\
\text { proposital das } \\
\text { condições de } \\
\text { trabalho }\end{array}$} & Retirar da vítima a autonomia \\
\hline & Não lhe transmitir mais as informações úteis para a realização de tarefas \\
\hline & Contestar sistematicamente todas as suas decisões \\
\hline & Criticar seu trabalho de forma injusta ou exagerada \\
\hline & Privá-la do acesso aos instrumentos de trabalho: telefone, fax, computador, entre outros \\
\hline & Retirar o trabalho que normalmente lhe compete \\
\hline & Dar-lhe permanentemente novas tarefas \\
\hline & Atribuir-lhe proposital e sistematicamente tarefas inferiores às suas competências \\
\hline & Atribuir-Ihe proposital e sistematicamente tarefas superiores às suas competências \\
\hline & Pressioná-la para que não faça valer seus direitos (férias, horários, prêmios) \\
\hline & Agir de modo a impedir que obtenha promoção \\
\hline & Atribuir à vítima, contra a vontade dela, trabalhos perigosos \\
\hline & Atribuir à vítima tarefas incompatíveis com sua saúde \\
\hline & Causar danos em seu local de trabalho \\
\hline & Dar-lhe deliberadamente instruções impossíveis de executar \\
\hline & Não levar em conta recomendações de ordem médica indicadas pelo médico do trabalho \\
\hline & Induzir a vítima ao erro \\
\hline \multirow{9}{*}{$\begin{array}{l}\text { Isolamento e } \\
\text { recusa de } \\
\text { comunicação }\end{array}$} & A vítima é interrompida constantemente \\
\hline & Superiores hierárquicos ou colegas não dialogam com a vítima \\
\hline & A comunicação com ela é unicamente por escrito \\
\hline & Recusa de todo contato com ela, mesmo o visual \\
\hline & É posta separada dos outros \\
\hline & Ignoram sua presença, dirigindo-se apenas aos outros \\
\hline & Proíbem os colegas de lhe falar \\
\hline & Já não a deixam falar com ninguém \\
\hline & A direção recusa qualquer pedido de entrevista \\
\hline \multirow{11}{*}{$\begin{array}{l}\text { Atentado contra a } \\
\text { dignidade }\end{array}$} & Utilizam insinuações desdenhosas para qualificá-la \\
\hline & $\begin{array}{l}\text { Fazem gestos de desprezo diante dela (suspiros, olhares desdenhosos, levantar de ombros, } \\
\text { entre outros }\end{array}$ \\
\hline & É desacreditada diante dos colegas, superiores ou subordinados \\
\hline & Espalham rumores a seu respeito \\
\hline & Atribuem-lhe problemas psicológicos (dizem que é doente mental) \\
\hline & Zombam de suas deficiências físicas ou de seu aspecto físico; é imitada ou caricaturada \\
\hline & Criticam sua vida privada \\
\hline & Zombam de suas origens ou de sua nacionalidade \\
\hline & Implicam com suas crenças religiosas ou convicções políticas \\
\hline & Atribuem-lhe tarefas humilhantes \\
\hline & É injuriada com termos obscenos ou degradantes \\
\hline
\end{tabular}




\begin{tabular}{|c|c|}
\hline \multirow{8}{*}{$\begin{array}{l}\text { Violência, verbal, } \\
\text { física ou sexual }\end{array}$} & Ameaças de violência física \\
\hline & Agridem-na fisicamente, mesmo que de leve, é empurrada, fecham-Ihe a porta na cara \\
\hline & Falam com ela aos gritos \\
\hline & Invadem sua vida privada com ligações telefônicas ou cartas \\
\hline & Seguem-na na rua, é espionada diante do domicílio \\
\hline & Fazem estragos em seu automóvel \\
\hline & É assediada ou agredida sexualmente (gestos ou propostas) \\
\hline & Não levam em conta seus problemas de saúde \\
\hline
\end{tabular}

Fonte: Extraído de HIRIGOYEN (2015).

Em relação à deterioração proposital das condições de trabalho, comprova-se que a maior frequência ocorre pelo assédio vertical (chefe para o subordinado). No que tange o assédio horizontal (entre pares), este relaciona-se com os atentados contra a dignidade e isolamento por parte de colegas e superiores. Por último, a ligação da violência verbal, física ou sexual se dá tanto pelos pares, quanto pelo superior hierárquico (HIRIGOYEN, 2015).

Em complemento, Barreto (2006) afirma que os comportamentos são variados, mas uma coisa é certa: sempre tem a determinação de atingir a vítima, desestabilizando-a emocionalmente, mesmo que não haja motivo plausível e concreto para tal situação. O propósito do agressor é dificultar o trabalho, atribuir erros imaginários, exigir desnecessariamente trabalhos urgentes, sobrecarregar de tarefas, estabelecer metas abusivas, restringir as pausas para refeição e/ou necessidades fisiológicas, fazer críticas ou brincadeiras de mau gosto em público e ameaçar e/ou insultar.

O assédio moral tem início com as relações interpessoais, entre agressor(es) e vítima(s), mas não se restringe apenas a essa questão. É sabido que 0 ambiente organizacional também influencia provocando este comportamento. Desta forma, podemos destacar que as organizações que respaldam seus discursos no bem-estar coletivo, mas que na prática isso não ocorre, acaba por gerar a ação hostil. Além disso, é comum ocorrer este tipo de assédio em empresas que focam excessivamente em resultados, no imediatismo e que provoquem a competitividade excessiva (TOLFO e KRAWULSKI, 2015).

\subsection{Assédio moral, danos morais e conflitos}

Para Venosa (2016) e Ferreira (2004), mesmo que sejam semelhantes, há que se diferenciar assédio moral de danos morais. Para os autores, é possível citar uma ação indesejável de forma isolada que, por mais ofensiva que seja, 
não se caracteriza como assédio moral. Desta forma, caso os elementos listados abaixo estejam presentes, há a caracterização do dano moral, mas não assédio moral:

- Agressões que não se estendem ao longo do tempo;

- Insulto ao grupo como um todo e não apenas uma pessoa específica;

- Circunstâncias precárias de trabalho, como escassez de material, má iluminação, espaço pequeno, entre outros;

- Causa danos à imagem, honra e privacidade;

- Imposições do exercício profissional, como advertência, avaliação de desempenho, transferência, entre outros.

Adicionalmente, a FIOCRUZ (2014, p. 15) denomina conflito como um "embate de diferentes culturas profissionais, visões de mundo (valores) diferentes, por tensões resultantes de reivindicações, por disputas de poder ou por recursos escassos". O conflito se diferencia do assédio moral pelo Quadro 2: 
Quadro 2: Diferenças entre Conflito e Assédio Moral

\begin{tabular}{|c|c|}
\hline Conflito & Assédio Moral \\
\hline $\begin{array}{l}\text { As divergências de visão } \\
\text { entre os profissionais são } \\
\text { deixadas às claras }\end{array}$ & $\begin{array}{l}\text { Agressões podem ser } \\
\text { difusas e implícitas }\end{array}$ \\
\hline $\begin{array}{l}\text { Profissionais envolvidos têm } \\
\text { consciência da divergência }\end{array}$ & $\begin{array}{l}\text { Interação confusa e } \\
\text { indefinida; nega-se a } \\
\text { existência do assédio }\end{array}$ \\
\hline $\begin{array}{l}\text { Comunicação direta e franca } \\
\text { entre profissionais que } \\
\text { possuem opiniões diferentes }\end{array}$ & $\begin{array}{l}\text { Comunicação se dá de forma } \\
\text { evasiva, dissimulada ou há } \\
\text { recusa ao diálogo }\end{array}$ \\
\hline $\begin{array}{l}\text { Não altera permanentemente } \\
\text { o clima organizacional }\end{array}$ & $\begin{array}{c}\text { Clima organizacional } \\
\text { conturbado }\end{array}$ \\
\hline $\begin{array}{c}\text { Há relacionamento } \\
\text { profissional direto entre } \\
\text { divergentes, ainda que } \\
\text { resolvam interromper o } \\
\text { diálogo acerca de um tema } \\
\text { especifico }\end{array}$ & $\begin{array}{l}\text { Pode haver recusa à } \\
\text { interação, isolamento }\end{array}$ \\
\hline $\begin{array}{c}\text { Confrontos e divergências } \\
\text { ocasionais }\end{array}$ & $\begin{array}{l}\text { Práticas antiéticas } \\
\text { duradouras e frequentes }\end{array}$ \\
\hline $\begin{array}{c}\text { Não objetiva prejudicar ou } \\
\text { afastar da organização o } \\
\text { profissional com visão } \\
\text { divergente }\end{array}$ & $\begin{array}{l}\text { Objetiva prejudicar a } \\
\text { situação do trabalhador na } \\
\text { organização, podendo levar } \\
\text { à demissão ou exoneração }\end{array}$ \\
\hline $\begin{array}{l}\text { Pode provocar antagonismo } \\
\text { entre grupos e sofrimento } \\
\text { compartilhado }\end{array}$ & $\begin{array}{l}\text { O assediado pode ser o único } \\
\text { alvo (o que não descarta o } \\
\text { assédio moral coletivo) }\end{array}$ \\
\hline
\end{tabular}

Fonte: Extraído de FUNDAÇÃO OSWALDO CRUZ, 2014.

\subsection{Diferenciações entre assédio moral e sexual}

Apesar deste trabalho não tratar do assédio sexual, é válido destacar a diferenciação destes para não os confundir. Para o Código Penal - art. 2016, a definição dessa forma de assédio se dá por constranger alguém para obtenção de benefícios ou "favorecimento sexual, prevalecendo-se o agente da sua condição de superior hierárquico ou ascendência inerentes ao exercício de emprego, cargo ou função - Pena: detenção, de 1 (um) a 2 (dois) anos" (PLANALTO, 2009). 
Analogamente, Robert Husbands, citado por Santos (2002, p. 30), considera o assédio sexual como "o praticado por um superior, geralmente, mas nem sempre, um homem, de exigir de um subordinado, geralmente, porém nem sempre, uma mulher, favores em contrapartida de certas vantagens profissionais".

No que se refere ao assédio moral, pode-se dizer que este ocorre de forma ascendente (subordinado para o chefe), horizontal, vertical ou mista (entre pares, juntamente com o chefe para o subordinado), enquanto o assédio sexual ocorre somente horizontal e de forma vertical. Ressaltando que o assédio vertical, tanto o moral quanto o sexual, causa maior dano para a saúde devido à visão da vítima em se sentir isolada e não encontrar a solução para o problema (HIRIGOYEN, 2015).

\subsection{Perfil do agressor}

De acordo com Barros (2009), os assediadores são perversos e narcisistas, além de depender de outras pessoas para viver, já que sua atuação solitária não surtirá efeito algum. Desta forma, conseguirá ter domínio da equipe de trabalho para então poder massacrar o assediado com a junção da plateia. Hirigoyen acrescenta que este é um ser:

“[...] Movido pela inveja, [...] tem um senso grandioso da própria importância, é absorvido por fantasias de sucesso ilimitado e de poder. Acredita ser especial e singular, pensa que tudo Ihe é devido; tem excessiva necessidade de ser admirado, e age como um vampiro. Não tem empatia, alimenta-se da energia dos que se veem seduzidos pelo seu charme; sente profunda inveja daqueles que parecem possuir coisas que the faltam, ou que simplesmente sabem extrair prazer da vida. São críticos ferinos; sentem prazer em criticar os outros, assim, provam-se onipotentes, diante da nulidade dos outros. Vazios e despossuídos de subjetividade, os perversos são seres irresponsáveis; por isso, ocultam-se, jogando os seus erros e limitações nos outros. Afinal, tudo que acontece de mal é sempre culpa dos outros". (HIRIGOYEN, 2015, p. 247) 


\subsection{Perfil da vítima}

Guedes (2008) cita que o assediado é o colaborador que se destaca por sua atuação e que possui qualidades profissionais e morais preciosas. É o profissional que tem algo a mais a oferecer e que o perverso se sente incomodado, acreditando que a vítima irá ocupar o seu lugar.

Em consonância, Prata (2008, p.180) afirma:

"Muitas vezes a vítima é o trabalhador mais brilhante, honesto, capaz e criativo do grupo. Originalidade implica coragem suficiente para transcender as normas geralmente aceitas. Algumas vezes isto implica ser mal compreendido ou rejeitado pelos companheiros. Quem não aceita as regras negativas impostas pela dinâmica grupal termina por despertar a cumplicidade dos mais medíocres a fim de persegui-lo com o objetivo de não criar competição. $\mathrm{Na}$ maior parte dos casos, o assediado é um trabalhador com forte investimento psicológico no trabalho, que ama a sua profissão e, por isso mesmo, vive com maior sofrimento em condição de marginalização."

\subsection{Causas e consequências}

São diversas as causas pelas quais o assédio moral se torna possível e a principal é a vontade do agressor que a vítima venha a se demitir por não conseguir aguentar a pressão. As demais causas se caracterizam pelas empresas buscarem resultados imediatos, incitando os líderes a fazer pressão nos subordinados, concentração de poder exageradamente forte (AGUIAR, 2008), recusa de um convite de saída, perseguição, má comunicação, estresse, influência do ambiente organizacional sobre os colaboradores, entre outros (ZANETTI, 2010).

Por fim, a FIOCRUZ (2014), mediante a Organização Mundial da Saúde (2003), levantou as doenças psicológicas que ocorreram com pessoas que sofreram com tal situação, chegando aos seguintes resultados: 
- Psicopatológica: ansiedade, apatia, insegurança, depressão, melancolia, irritação, insônia, mudança de humor, pânico e fobias e pesadelos.

- Psicossomática: hipertensão arterial, ataques de asma, taquicardia, doenças coronarianas, dermatites, cefaleia, dores musculares e gastrite.

- Comportamental: agressividade contra si e contra os outros, aumento do consumo de álcool e drogas, aumento do consumo de cigarros, disfunções sexuais, isolamento social e desordens de apetite.

O Quadro 3 a seguir ilustra o relato anterior de forma mais clara:

\section{Quadro 3: Consequências do Assédio Moral}

\begin{tabular}{|c|c|c|}
\hline Psicopatológica & Psicossomáticas & Comportamental \\
\hline Ansiedade & Hipertensão arterial & $\begin{array}{l}\text { Agressividade contra si e contra } \\
\text { os outros }\end{array}$ \\
\hline Apatia & Ataques de asma & $\begin{array}{l}\text { Aumento do consumo de álcool } \\
\text { e drogas }\end{array}$ \\
\hline Insegurança & Taquicardia & $\begin{array}{l}\text { Aumento do consumo de } \\
\text { cigarros }\end{array}$ \\
\hline Depressão & Doenças coronarianas & Disfunções sexuais \\
\hline Melancolia & Dermatites & Isolamento social \\
\hline Irritação & Cefaleia & Desordens de apetite \\
\hline Insônia & Dores musculares & \\
\hline Mudança de humor & Gastrite & \\
\hline Pânico e fobias & & \\
\hline Pesadelos & & \\
\hline
\end{tabular}

Fonte: FUNDAÇÃO OSVALDO CRUZ, 2014

Diante do exposto, conforme o arcabouço teórico apresentado, o presente estudo investigou as causas e as consequências do assédio moral identificadas pelos sujeitos pesquisados, vítimas deste evento. 


\section{Metodologia}

\subsection{Processo da análise e interpretação dos dados}

Com o intuito de responder corretamente à pergunta problema deste estudo, o procedimento descrito na sequência foi:

Figura 1: Processo de análise e interpretação dos dados

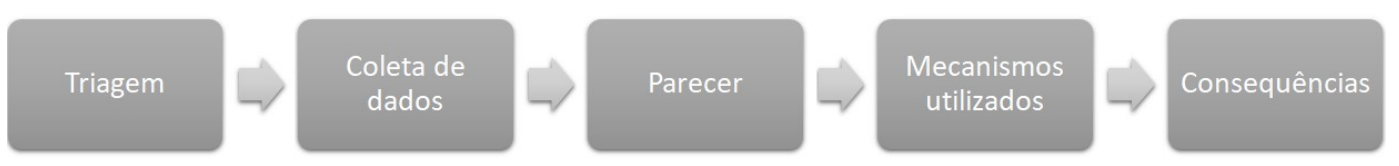

Fonte: Autoria própria

Em primeiro lugar, houve a triagem dos indivíduos que consideravam ter passado pelo assédio moral no trabalho, com a coleta de dados de suas informações por meio de entrevista. Em seguida, a pesquisadora elaborou um parecer dos dados confrontando-os com a Lei 5.452/43 de 01 de maio de 1943, Art $^{\circ} 483$ para julgar se a vivência de fato se enquadrou como tal e realizar a filtragem necessária para prosseguir para a próxima etapa. Após, a análise qualitativa de dados foi empregada para relacionar as falas dos entrevistados com os mecanismos utilizados pelos assediadores identificados e as consequências do episódio identificadas pelos respondentes. Nos tópicos que se seguem serão abordados cada um desses itens.

\subsection{Tipo de Pesquisa}

A natureza do estudo é qualitativa e possui a intenção de fornecer relatos de fenômenos sem a necessidade de obtenção de medidas numéricas e "seu foco está em descobrir verdadeiras 'propriedades' e abrir novas perspectivas" (ZIKMUND e BABIN, 2011, p. 110). Além disso, o tipo de pesquisa é descritivo, que serve para descrever características de objetos, organizações, ambientes, pessoas ou grupos, tentando retratar uma determinada situação, não havendo a necessidade de ser uma pesquisa conclusiva, mas sim de contribuir com um 
assunto já existente, proporcionando, assim, uma nova visão para a temática (VERGARA, 2003).

\subsection{Procedimentos e instrumentos de coleta de dados utilizados no estudo}

Para que a obtenção de respostas fosse possível, a seleção da técnica se deu pela entrevista semiestruturada com um roteiro contendo ideias centrais relativas ao tema de estudo, além de contar com perguntas adicionais para compreender melhor o contexto do caso, se houvesse necessidade. As entrevistas foram realizadas majoritariamente de forma presencial e com uma pequena parcela através de ligações telefônicas. Vale lembrar que o candidato estava consciente de que haveria gravação e transcrição das entrevistas para uma análise adequada, objetivando coletar o máximo de dados e informações possíveis, mas que sua identidade seria preservada.

No primeiro momento, o roteiro da entrevista procurou compreender a percepção dos entrevistados acerca do tema, exposição as situações ocorridas, se houve um agente externo intercedendo por eles, a reação dos interrogados e as decorrências dessa reação. Ao final, perguntas direcionadas foram realizadas a fim de determinar as consequências da vivência do fenômeno em suas vidas.

\subsection{Fontes de informação selecionadas para coleta de dados no estudo}

Os indivíduos selecionados foram vizinhos e colegas da autora, bem como as pessoas que os próprios entrevistados indicaram. A seleção destes para prosseguimento na pesquisa foi realizada prezando os perfis distintos, a fim de se obter uma abrangência de dados e informações que contribuíssem satisfatoriamente para o estudo. Desta forma, a triagem se deu por meio dos trabalhadores que consideravam ter passado pela temática, oriundos de empresas privadas de diferentes universidades e/ou localidades, segmentos e portes organizacionais dentro do Estado do Rio de Janeiro, com um mínimo de três meses de contato com o assédio moral nos últimos seis anos. As pessoas poderiam ter mais tempo de casa e o assédio deveria ter ocorrido mais recentemente, como é o caso da E9 que possuía 14 anos de empresa, mas que o assédio começou a acontecer nos últimos 5 anos de casa.

Ao total, a pesquisa contou com vinte e quatro respondentes voluntários. Após isso, considerou-se possuir o número suficiente de entrevistados para 
cumprir com o perfil abordado, além de obter informações desejadas para a coleta de dados. Com o objetivo de sintetizar o relato anterior, o Quadro 4 a seguir exibe as informações dos candidatos:

\section{Quadro 4: Perfil dos entrevistados}

\begin{tabular}{|c|c|c|c|c|c|c|c|c|c|}
\hline Ref. & Sexo & Idade & Formação & Cargo & $\begin{array}{c}\text { Tempo } \\
\text { de } \\
\text { casa }\end{array}$ & Setor & $\begin{array}{c}\text { Empresa } \\
\text { atual? }\end{array}$ & $\begin{array}{l}\text { Escopo de } \\
\text { atuação }\end{array}$ & Porte \\
\hline E1 & M & 25 & $\begin{array}{l}\text { Superior } \\
\text { cursando }\end{array}$ & $\begin{array}{l}\text { Estagiário de } \\
\text { Vendas }\end{array}$ & $\begin{array}{c}6 \\
\text { meses }\end{array}$ & Óleo e Gás & Não & Multinacional & Grande \\
\hline E2 & $\mathrm{F}$ & 27 & $\begin{array}{l}\text { Superior } \\
\text { completo }\end{array}$ & $\begin{array}{l}\text { Anl. de T\&D } \\
\text { PL }\end{array}$ & 3 anos & Imobiliária & Sim & $\begin{array}{l}\text { Familiar } \\
\text { regional }\end{array}$ & Médio \\
\hline E3 & $\mathrm{F}$ & 38 & $\begin{array}{c}\text { E.M. } \\
\text { Incompleto }\end{array}$ & $\begin{array}{l}\text { Operador de } \\
\text { caixa }\end{array}$ & 4 anos & Alimentício & Não & $\begin{array}{l}\text { Não familiar } \\
\text { regional }\end{array}$ & Pequeno \\
\hline E4 & M & 26 & $\begin{array}{l}\text { Superior } \\
\text { cursando }\end{array}$ & $\begin{array}{c}\text { Anl. de } \\
\text { Operações JR }\end{array}$ & $\begin{array}{c}2,5 \\
\text { anos }\end{array}$ & E-commerce & Sim & $\begin{array}{l}\text { Não familiar } \\
\text { nacional }\end{array}$ & Médio \\
\hline E5 & $\mathrm{F}$ & 23 & $\begin{array}{l}\text { Superior } \\
\text { cursando }\end{array}$ & $\begin{array}{l}\text { Estagiário de } \\
\text { Medicina }\end{array}$ & 2 anos & Saúde & Sim & $\begin{array}{l}\text { Não familiar } \\
\text { nacional }\end{array}$ & Grande \\
\hline E6 & $\mathrm{F}$ & 24 & $\begin{array}{l}\text { Superior } \\
\text { cursando }\end{array}$ & $\begin{array}{c}\text { Estagiário de } \\
\text { Finanças e } \\
\text { Análises }\end{array}$ & $\begin{array}{l}1,5 \\
\text { ano }\end{array}$ & Tecnologia & Sim & Multinacional & Grande \\
\hline E7 & M & 23 & $\begin{array}{l}\text { Superior } \\
\text { cursando }\end{array}$ & $\begin{array}{c}\text { Anl. de } \\
\text { Atendimento } \\
\text { PL }\end{array}$ & 4 anos & Saúde & Sim & $\begin{array}{l}\text { Não familiar } \\
\text { regional }\end{array}$ & Médio \\
\hline E8 & $\mathrm{O}$ & 22 & $\begin{array}{l}\text { Superior } \\
\text { cursando }\end{array}$ & $\begin{array}{c}\text { Auxiliar de } \\
\text { Loja }\end{array}$ & $\begin{array}{c}10 \\
\text { meses }\end{array}$ & Varejo & Não & $\begin{array}{c}\text { Não familiar } \\
\text { nacional }\end{array}$ & Grande \\
\hline E9 & $F$ & 58 & $\begin{array}{c}\text { E.M. } \\
\text { Completo }\end{array}$ & $\begin{array}{c}\text { Assistente de } \\
\text { Controle de } \\
\text { Qualidade III }\end{array}$ & $\begin{array}{c}14 \\
\text { anos }\end{array}$ & Silicone & Não & Multinacional & Grande \\
\hline E10 & $\mathrm{F}$ & 23 & $\begin{array}{l}\text { Superior } \\
\text { completo }\end{array}$ & $\begin{array}{l}\text { Telemarketing } \\
\text { de Ouvidoria }\end{array}$ & 4 anos & Ouvidoria & Não & $\begin{array}{l}\text { Familiar } \\
\text { regional }\end{array}$ & Grande \\
\hline E11 & M & 24 & Técnico & $\begin{array}{c}\text { Técnico em } \\
\text { Eletrotécnica II }\end{array}$ & 8 anos & Vidro & Sim & Multinacional & Grande \\
\hline E12 & M & 23 & $\begin{array}{l}\text { Superior } \\
\text { cursando }\end{array}$ & $\begin{array}{c}\text { Auxiliar de } \\
\text { Loja }\end{array}$ & 5 anos & Varejo & Não & $\begin{array}{l}\text { Não familiar } \\
\text { regional }\end{array}$ & Médio \\
\hline E13 & $\mathrm{F}$ & 28 & $\begin{array}{l}\text { Superior } \\
\text { cursando }\end{array}$ & Secretária & 4 anos & Educacional & Sim & $\begin{array}{c}\text { Não familiar } \\
\text { regional }\end{array}$ & Médio \\
\hline E14 & M & 32 & $\begin{array}{c}\text { E.M. } \\
\text { Completo }\end{array}$ & Garçom & 9 anos & Alimentício & Sim & $\begin{array}{l}\text { Familiar } \\
\text { regional }\end{array}$ & Pequeno \\
\hline E15 & M & 21 & $\begin{array}{l}\text { Superior } \\
\text { cursando }\end{array}$ & $\begin{array}{c}\text { Assistente } \\
\text { Administrativo } \\
\text { I }\end{array}$ & 3 anos & $\begin{array}{c}\text { Construção } \\
\text { Civil }\end{array}$ & Sim & $\begin{array}{l}\text { Familiar } \\
\text { regional }\end{array}$ & Grande \\
\hline E16 & M & 32 & $\begin{array}{l}\text { Pós- } \\
\text { graduação } \\
\text { completa }\end{array}$ & $\begin{array}{c}\text { Anl. de Planej. } \\
\text { Orçamentário } \\
\text { e Indicadores } \\
\text { PL }\end{array}$ & 6 anos & Entretenimento & Não & Multinacional & Grande \\
\hline E17 & $F$ & 21 & $\begin{array}{l}\text { Superior } \\
\text { cursando }\end{array}$ & $\begin{array}{l}\text { Estagiário de } \\
\text { Direito }\end{array}$ & 2 anos & $\begin{array}{c}\text { Consultoria } \\
\text { Jurídica }\end{array}$ & Não & $\begin{array}{l}\text { Não familiar } \\
\text { regional }\end{array}$ & Grande \\
\hline E18 & M & 27 & $\begin{array}{l}\text { Superior } \\
\text { cursando }\end{array}$ & $\begin{array}{c}\text { Assistente } \\
\text { Comercial PL }\end{array}$ & 8 anos & $\begin{array}{c}\text { Corretagem de } \\
\text { Seguros }\end{array}$ & Sim & $\begin{array}{c}\text { Não familiar } \\
\text { nacional }\end{array}$ & Pequeno \\
\hline E19 & M & 27 & $\begin{array}{l}\text { Superior } \\
\text { cursando }\end{array}$ & $\begin{array}{c}\text { Estagiário de } \\
\text { Jornalismo }\end{array}$ & $\begin{array}{c}10 \\
\text { meses }\end{array}$ & $\begin{array}{c}\text { Jornalismo de } \\
\text { Esportes }\end{array}$ & Não & $\begin{array}{l}\text { Familiar } \\
\text { nacional }\end{array}$ & Grande \\
\hline E20 & $F$ & 23 & $\begin{array}{l}\text { Superior } \\
\text { completo }\end{array}$ & $\begin{array}{c}\text { Agente } \\
\text { Comercial }\end{array}$ & 2 anos & Financeiro & Não & $\begin{array}{c}\text { Não familiar } \\
\text { nacional }\end{array}$ & Grande \\
\hline E21 & $\mathrm{F}$ & 38 & $\begin{array}{c}\text { Pós- } \\
\text { graduação } \\
\text { completa }\end{array}$ & $\begin{array}{c}\text { Anl. de } \\
\text { Endomarketing } \\
\text { PL }\end{array}$ & 6 anos & Incorporadora & Sim & $\begin{array}{l}\text { Familiar } \\
\text { regional }\end{array}$ & Grande \\
\hline
\end{tabular}




\begin{tabular}{|cccccccccc|}
\hline E22 & F & 23 & $\begin{array}{c}\text { Superior } \\
\text { cursando }\end{array}$ & $\begin{array}{c}\text { Estagiário } \\
\text { Administrativo }\end{array}$ & 1 ano & Educacional & Não & $\begin{array}{c}\text { Não familiar } \\
\text { nacional }\end{array}$ & Grande \\
\hline E23 & F & 23 & $\begin{array}{c}\text { Superior } \\
\text { cursando }\end{array}$ & $\begin{array}{c}\text { Estagiário de } \\
\text { Recursos } \\
\text { Humanos }\end{array}$ & $\begin{array}{c}3 \\
\text { meses }\end{array}$ & Turismo & $\begin{array}{c}\text { Não familiar } \\
\text { nacional }\end{array}$ & Médio \\
\hline E24 & M & 25 & $\begin{array}{c}\text { Superior } \\
\text { completo }\end{array}$ & Bancário & 5 anos & Financeiro & Sim & $\begin{array}{c}\text { Não familiar } \\
\text { nacional }\end{array}$ & Grande \\
\hline
\end{tabular}

Fonte: Autoria própria

\subsection{Formas de tratamento e análise dos dados coletados para o estudo}

Como se trata de uma pesquisa qualitativa com a coleta de dados e informações através de roteiros semiestruturados, foi aplicada a análise qualitativa de dados das entrevistas que, de acordo com Miles e Huberman (1994), apresenta as etapas de redução, apresentação e conclusão.

No primeiro aspecto, há a presença de seleção e simplificação dos dados e das informações obtidas pelo campo e a posterior confrontação com a fundamentação teórica da pesquisa. Já a apresentação equivale a organização destes e exposição de forma simplificada através de textos, diagramas, entre outros. Por último, a conclusão diz respeito ao significado, explicações e padrões.

Desta forma, viabilizou-se captar diálogos do discurso, fragmentá-los para determinar se as premissas são atendidas, categorizá-los relacionando com os mecanismos utilizados, relacionando, então, com as consequências do ato. Em específico, foi obtido o parecer segundo a lei brasileira 5.452/43 de 01 de maio de 1943, Art $^{\circ}$ 483. Em sequência, houve a filtragem dos indivíduos que se enquadraram na categoria de assediados de acordo com a legislação abordada, a categorização de suas falas com os mecanismos de atitudes hostis utilizados segundo Hirigoyen (2015) e outros emergidos do campo, bem como os problemas de saúde resultantes da ação.

Dentre os entrevistados, desconsideraram-se os E5, E10, E12, E14, E15, E18 e E22 por possuírem apenas uma ocorrência, não caracterizando, assim, o assédio moral pela falta de repetição prolongada e sistemática e temporalidade ou frequência dos casos.

\subsection{Limitações do método}

A exploração do assunto decorreu em um histórico específico e tempo limitados a esse entendimento. Sendo assim, o trabalho poderá contribuir para inspirar outras pesquisas nos demais momentos, utilizando-se de pressupostos 
destacados. No que tange à percepção da pesquisadora acerca da análise e diagnóstico, este também configura como limitação da pesquisa qualitativa, visto que os vieses podem introduzir certa distorção nas interpretações. Para diminui-los, as técnicas de entrevistas nos estudos descritivos (GIL, 2011) e de análise de dados (MILES e HUBERMAN, 1994) foram cuidadosamente utilizadas conforme os respectivos autores. Em relação aos entrevistados, as limitações se destinam à incompreensão das perguntas, desmotivação em respondê-las, retenção de informações ou respostas falsas para preservar a sua identidade. Dois entrevistados demonstraram desinteresse, entretanto, suas entrevistas foram eliminadas por não se configurarem assédio moral.

Apesar das limitações expostas, o método demonstrou-se indicado para o estudo realizado, pois viabiliza a interpretação aprofundada e compreensiva do conteúdo. 


\section{Apresentação e Análise dos Resultados}

\subsection{Categorização do assédio moral}

Conforme apresentado na Metodologia, as informações foram obtidas através de entrevista individual semiestruturada e, após serem realizadas as filtragens necessárias dos dados para considerar apenas os dos assediados, houve o enquadramento das respostas aos mecanismos utilizados conforme as atitudes hostis de Hirigoyen (2015) e demais categorias emergidas do campo. Vale ressaltar que a ausência de enquadramento em determinados elementos não exclui a caracterização de assédio moral no trabalho, sendo demonstrado apenas de maneiras distintas. Além disso, as respostas foram ordenadas de acordo com a categorização do método.

\subsection{Categoria 1 - Atitude hostil}

Nesta categoria, Hirigoyen (2015) engloba as dimensões que proporcionam o acontecimento do assédio moral, são elas: deterioração proposital das condições de trabalho, isolamento e recusa da comunicação, atentado contra a dignidade e violência verbal, física ou sexual. Conforme abordado anteriormente, essas classes são demonstradas das mais sutis para as mais perceptíveis. Dentro de cada subcategoria existem os elementos de análise que serão discutidos no decorrer do estudo.

\subsubsection{Subcategoria 1: Deterioração proposital das condições de trabalho}

A deterioração proposital das condições de trabalho relaciona-se com o prejuízo no que tange a vítima parecer incapaz, levando os superiores hierárquicos se valerem do direito de criticar rigorosamente, passando, inclusive, dos limites com isso, além de obter justificativa para uma possível demissão. Como esta é representada nas entrelinhas, a dificuldade de sua comprovação aumenta, já que a culpa sempre será do assediado, conforme o mecanismo é exercido pelo assediador. Porém, quando combinada com as demais subcategorias, a percepção se torna mais fácil de ser identificada. 
Nessa subcategoria, os itens que mais apareceram na pesquisa foram a não transferência das informações úteis para a realização de tarefas e crítica do trabalho de forma injusta e exagerada.

Durante as respostas, os entrevistados afirmaram que nas primeiras vezes que esses elementos de análise ocorreram, eles não consideraram como assédio moral, mas sim somente com a junção do todo e após um tempo passando pela situação. Isso vai ao encontro da afirmação de Hirigoyen (2015), em que esses aspectos são mais difíceis de serem vistos facilmente.

A autora declara que esses elementos ocorrem através de superiores hierárquicos para com os subordinados, porém a fala de E11 se diferenciou. Ele afirmou que, além dos chefes, os seus pares também responsáveis por disseminar informações praticavam o oposto.

Abaixo, estão ilustrados no Quadro 5 os elementos de análise dessa subcategoria e a relação deles com as falas dos entrevistados.

\section{Quadro 5: Deterioração proposital das condições de trabalho}

\begin{tabular}{|c|c|}
\hline Elemento de análise & Exemplos \\
\hline & $\begin{array}{l}\text { "Ele (chefe) já também abriu o meu armário, [...] pegou minhas coisas e botou no armário da } \\
\text { outra pessoa [...]. Eu não tinha a menor intimidade com ele, eu tava trabalhando há duas } \\
\text { semanas aqui na [Nome da Empresa] e eu fiquei bem bolada." (E6) }\end{array}$ \\
\hline $\begin{array}{l}\text { Retirar da vítima a } \\
\text { autonomia }\end{array}$ & $\begin{array}{l}\text { "[...] Eu queria muito trabalhar na editoria de automobilismo. O gerente da área me chamou } \\
\text { duas vezes pra trabalhar lá e o meu gerente da editoria Nordeste disse que isso não seria } \\
\text { possível, porque [...] a primeira editoria que seria cortada era a de automobilismo, [...] sendo } \\
\text { que meses depois a empresa fez um mega pacote de produtos [...]. Ele sabia que se eu } \\
\text { saísse, eu era a única pessoa que tava segurando aquela onda ali e que não haveria outra } \\
\text { pessoa que faria o meu trabalho. [...] Eram me dadas justificativas que não condiziam [...] com } \\
\text { o planejamento estratégico da empresa, como [...] a questão [...] do desinvestimento nessas } \\
\text { categorias de automobilismo." (E19) }\end{array}$ \\
\hline \multirow{4}{*}{$\begin{array}{l}\text { Não Ihe transmitir } \\
\text { mais as informações } \\
\text { úteis para a } \\
\text { realização de tarefas }\end{array}$} & $\begin{array}{l}\text { "[...] Desde o primeiro dia do trabalho tinha uma distância [...] entre eu e ele (chefe). Ele não } \\
\text { era presente, parecendo que não tava lá [...]. Ele não se preocupava em me ensinar, em me } \\
\text { mostrar as coisas. Eu sentia um estresse muito grande da parte dele quando ia me ensinar. } \\
\text { [...] Então existia uma falta de orientação, uma falta de apoio, de suporte, que era propagado } \\
\text { pela equipe também." (E1) }\end{array}$ \\
\hline & $\begin{array}{l}\text { "Ele (chefe) também não passava as informações direito pra mim e quando alguém vinha e } \\
\text { falava alguma coisa comigo eu ficava vendida, porque eu não sabia da informação correta ou } \\
\text { ele não passava mesmo. Preferia passar para uma funcionária que fazia parte do grupinho da } \\
\text { fofoca do que pra mim que fazia a mesma coisa que ele, que ela da área que ele." (E2) }\end{array}$ \\
\hline & $\begin{array}{l}\text { "Ele (chefe) faz várias coisas no trabalho mesmo que não são devidas e [...] ele guarda muita } \\
\text { informação, muita mesmo." (E6) }\end{array}$ \\
\hline & $\begin{array}{l}\text { "Eu estava literalmente para aprender ali e eles (chefes e colegas de trabalho) acharam isso } \\
\text { algo inadmissível, não queriam me ensinar. Falavam que eu fazia } \mathrm{m}^{\star * \star *} \text {, mas ninguém me } \\
\text { ensinava, ninguém se preocupava." (E11) }\end{array}$ \\
\hline \multirow{2}{*}{$\begin{array}{l}\text { Contestar } \\
\text { sistematicamente } \\
\text { todas as suas } \\
\text { decisões }\end{array}$} & $\begin{array}{l}\text { "Eu percebia [...] que quanto mais eu me destacava, quanto mais eu recebia elogios de } \\
\text { clientes, mais no meu pé ele (chefe) ficava. [...] Sempre que ele decidia aporrinhar as nossas } \\
\text { ideias ele ficava questionando as coisas que a gente fazia, mesmo sem motivo." (E3) }\end{array}$ \\
\hline & $\begin{array}{l}\text { "Ele (chefe) ficava também vendo tudo que você fazia, tudo mesmo, sem exceção. Detalhe por } \\
\text { detalhe. Só pra ver se você errava pra ter quem criticar. Na verdade, nem precisava errar, } \\
\text { porque ele já ficava assumindo que tava errado." (E8) }\end{array}$ \\
\hline
\end{tabular}




\begin{tabular}{|c|c|}
\hline \multirow{4}{*}{$\begin{array}{l}\text { Criticar seu trabalho } \\
\text { de forma injusta ou } \\
\text { exagerada }\end{array}$} & $\begin{array}{l}\text { "Sempre que eu ia mostrar o trabalho que eu tinha feito, né, ele (chefe) ficava falando 'tá uma } \\
\mathrm{m}^{\star \star \star \star} \text {, dá até medo de ver', antes mesmo de ver [...]. Ele falava sério isso. Na primeira vez eu } \\
\text { até ri achando que era brincadeira e ele me perguntou se ele tinha cara de palhaço." (E2) }\end{array}$ \\
\hline & $\begin{array}{l}\text { "Ele (chefe) ficava, tipo, 'por que tá fazendo isso? Não tá fazendo direito', sendo que ele tinha } \\
\text { orientado daquela maneira." (E8) }\end{array}$ \\
\hline & $\begin{array}{l}\text { "(chefe) sempre fazendo críticas aos atendimentos com os alunos, sempre tendo algo negativo } \\
\text { a se falar e nunca algo positivo. [...] Os alunos têm me procurado de manhã e elogiado meu } \\
\text { atendimento." (E13) }\end{array}$ \\
\hline & $\begin{array}{l}\text { "[...] Sempre havia desaprovação em qualquer que fosse o meu comportamento. Tudo que eu } \\
\text { fazia ela (chefe) criticava. Não passava nada com ela." (E17) }\end{array}$ \\
\hline $\begin{array}{l}\text { Retirar o trabalho } \\
\text { que normalmente } \\
\text { lhe compete }\end{array}$ & $\begin{array}{l}\text { "Em várias situações em que ela (chefe) tinha oportunidade, ela dizia 'eu sou a coordenadora, } \\
\text { eu faço', e tirava o nosso trabalho do dia a dia. E pior, ela fazia questão de falar pra todo } \\
\text { mundo o que tava acontecendo, que ela tava tirando o trabalho rotineiro de um incapaz." (E7) }\end{array}$ \\
\hline $\begin{array}{l}\text { Dar-lhe } \\
\text { permanentemente } \\
\text { novas tarefas }\end{array}$ & $\begin{array}{l}\text { "O meu chefe era tão filho da p*** que ele, no cargo de Gestão, ficava me passando todo o } \\
\text { trabalho dele. Eu, uma Analista Pleno, fazendo trabalho de Gerente. Onde já se viu? É o poste } \\
\text { mijando no cachorro. E ai se eu não fizesse, ein. Tomava um esporro que você não imagina." } \\
\text { (E2) }\end{array}$ \\
\hline \multirow{2}{*}{$\begin{array}{c}\text { Atribuir-lhe } \\
\text { proposital e } \\
\text { sistematicamente } \\
\text { tarefas superiores } \\
\text { às suas } \\
\text { competências }\end{array}$} & $\begin{array}{l}\text { "Depois de um tempo, eu era a faz tudo, mesmo com a minha carteira assinada como Caixa } \\
\text { apenas. Aí eu fazia de tudo, porque ele (chefe) mandava fazer: limpava chão, tirava prato, } \\
\text { tirava o pedido dos cliente e muitas outras coisas e mesmo assim ele não largava com essas } \\
\text { cobranças 'desembestadas'." (E3) }\end{array}$ \\
\hline & $\begin{array}{l}\text { "Me colocaram (chefes) numa posição de gerente, entre aspas, sem ganhar pra isso, sem } \\
\text { estrutura formal, nem nada, num cargo totalmente operacional [...] e aí eu atendia como } \\
\text { gerente, tinha metas de gerente, [...] mas tinha que fazer isso numa carga horária de Agente } \\
\text { Comercial, de } 6 \text { horas, e também eu não tinha nenhuma experiência." (E20) }\end{array}$ \\
\hline \multirow{2}{*}{$\begin{array}{l}\text { Pressioná-la para } \\
\text { que não faça valer } \\
\text { seus direitos (férias, } \\
\text { horários, prêmios) }\end{array}$} & $\begin{array}{l}\text { "Ela (chefe encarregada) chamava uma pessoa que se aliou a ela [...] e ficava interrogando o } \\
\text { que eu tinha feito [...]. Um dia, o único extra [...] que eu fiz, [...] ela não estava na empresa e } \\
\text { minha chefe (gerente) me perguntou se eu podia fazer esse extra. A encarregada quando } \\
\text { soube, [...] ela ficou muito, muito mesmo furiosa, me deu uma bronca na frente de algumas } \\
\text { pessoas [...]. Disse até que não ia mais autorizar essas horas e as seguintes. [...] Para tirar } \\
\text { férias era um parto, porque ela fazia com que eu tirasse sempre atrasado e em meses que não } \\
\text { era legais pra mim." (E9) }\end{array}$ \\
\hline & 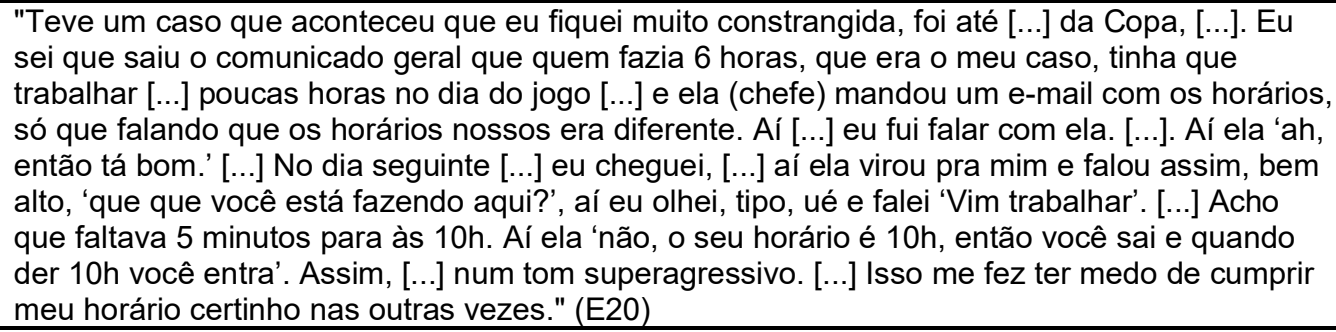 \\
\hline $\begin{array}{l}\text { Agir de modo a } \\
\text { impedir que obtenha } \\
\text { promoção }\end{array}$ & $\begin{array}{l}\text { "Isso é muito comum no banco. Quando você erra, você é muito escrachado ou quando você } \\
\text { não tá produzindo muito, você é escrachado. Até se você for o primeiro lugar, meses você tá } \\
\text { entregando em primeiro lugar, aí tem um mês específico que você não entrega, você também } \\
\text { é escrachado [...]. Teve esse [...] papo de tipo 'ah, pô, [Nome do Entrevistado], eu preciso que } \\
\text { você faça uma campanha pra mobilizar tua agência [...]'. Eu fiz, né, com promessa de } \\
\text { promoção da minha chefe e tal e não deu em nada. A gente entregou } 150 \% \text { da meta, todos os } \\
\text { resultados foram bons [...] e eles (chefes) pegaram [...] um item de toda grade de produtos [...], } \\
\text { com } 80 \% \text { [...] pra justificar. Falaram 'ah, [Nome do Entrevistado], sabia que a sua agência tá } \\
\text { puxando a região pra baixo nesse item? Esse item tá muito mal'." (E24) }\end{array}$ \\
\hline $\begin{array}{l}\text { Induzir a vítima ao } \\
\text { erro }\end{array}$ & $\begin{array}{l}\text { "Ele (chefe) me pediu uma demanda e eu fazia conforme ele tinha pedido e aí depois ele } \\
\text { falava que estava errado, que não era aquilo que ele tinha pedido. A minha sorte foi que } \\
\text { algumas vezes ele encaminhou um e-mail pra mim falando qual a demanda que era pra ser } \\
\text { feita e eu conseguia comprovar. Fora isso, eu acabava me ferrando porque ele achava que } \\
\text { estava certo e que podia falar qualquer coisa, brigava comigo, falava que eu tava dando mole, } \\
\text { que eu já fui melhor, que até uma criança de } 5 \text { anos consegue fazer e eu não e até uma } \\
\text { criança de } 5 \text { anos consegue entender e eu não." (E2) }\end{array}$ \\
\hline
\end{tabular}

Fonte: Autoria própria 


\subsubsection{Subcategoria 2: Isolamento e recusa de comunicação}

No isolamento e recusa de comunicação, é comum a vítima ser excluída do meio social pelos chefes e colegas de trabalho. O intuito de distanciá-la da interação social através das diversas justificativas ocasiona em um infeliz sentimento ressentido de forma profunda, mas com uma visão oposta e banalizada pelo assediador.

Os elementos de maior recorrência nesta subcategoria foram os superiores hierárquicos ou colegas não dialogarem com a vítima e ignorarem a sua presença, dirigindo-se apenas aos outros colaboradores. Nessas questões, os entrevistados proclamaram que começaram a desconfiar que algo não estava certo por ser mais perceptível e que se sentiam banidos do grupo sem motivo algum.

Além disso, as falas vão ao encontro do que Hirigoyen (2015) expressou, sobre as ações poderem se suceder tanto pelos superiores hierárquicos, quanto pelos colegas de trabalho.

Os relatos que se seguem no Quadro 6 ilustram a relação com cada elemento de análise da presente subcategoria.

\section{Quadro 6: Isolamento e recusa de comunicação}

\begin{tabular}{|c|c|}
\hline Elemento de análise & Exemplos \\
\hline $\begin{array}{l}\text { A vítima é } \\
\text { interrompida } \\
\text { constantemente }\end{array}$ & $\begin{array}{l}\text { "Não houve ação por parte de ninguém (colegas de trabalho), mesmo presenciando aquilo } \\
\text { tudo. Pelo contrário, eles começaram a se afastar da situação e até mesmo a distorcer a } \\
\text { história. Ficavam perguntando por que não fui forte, por que não aguentei até o final. Quando } \\
\text { ia responder, eles não queriam ouvir, não valia a pena ouvir o que eu tinha pra dizer, já que } \\
\text { quem estava de saída era eu. O próprio } \mathrm{RH} \text {, inclusive, me ouviu muito pouco e ficou me } \\
\text { interrompendo para perguntar por que não tinha feito algo quando pude e que eu poderia estar } \\
\text { aumentando a história, que naquela empresa era normal os engenheiros terem esse jeitão." } \\
\text { (E1) }\end{array}$ \\
\hline \multirow{2}{*}{$\begin{array}{l}\text { Superiores } \\
\text { hierárquicos ou } \\
\text { colegas não } \\
\text { dialogam com a } \\
\text { vítima }\end{array}$} & $\begin{array}{l}\text { "Eventualmente foi rolando afastamento entre eu e ele (chefe) a ponto que no trabalho eu não } \\
\text { conseguia mais conversar com ele. Não restou respeito, não tinha uma relação de respeito da } \\
\text { parte dele e ele não entendia como deveria se portar diante de mim tanto de maneira física } \\
\text { quanto verbal." (E1) }\end{array}$ \\
\hline & $\begin{array}{l}\text { "Eu fiquei chateada, porque eu não senti que eu tava tendo apoio, eu não senti que tava sendo } \\
\text { desenvolvida no meu trabalho. Eu sou uma estagiária, tinha um monte de dúvida e aí [...] as } \\
\text { coisas que eu queria perguntar, eu já não queria mais perguntar mais pra ela (chefe) já que } \\
\text { nitidamente ela estava nem aí [...] pelo meu trabalho, pelas coisas que eu tava fazendo. Nem } \\
\text { falar comigo ela falava. Ficava me ignorando." (E23) }\end{array}$ \\
\hline $\begin{array}{l}\text { A comunicação com } \\
\text { ela é unicamente } \\
\text { por escrito }\end{array}$ & $\begin{array}{l}\text { "Ela (coordenadora de outra área) só fala comigo por e-mail. Não me liga para alinhar os } \\
\text { trabalhos e só sai pegando tudo pra ela. Passa por cima da minha autorização das áreas que } \\
\text { eu tomo conta. É um circo que só." (E21) }\end{array}$ \\
\hline $\begin{array}{l}\text { Recusam todo } \\
\text { contato com ela, } \\
\text { mesmo o visual }\end{array}$ & $\begin{array}{l}\text { "No início pensei que fosse coisa da minha cabeça, mas percebi que eles (colegas de trabalho) } \\
\text { só dirigiam o olhar pra mim quando eu era zoada. Tirando isso, não." (E2) }\end{array}$ \\
\hline
\end{tabular}




\begin{tabular}{|c|c|}
\hline \multirow[b]{2}{*}{$\begin{array}{l}\text { Ignoram sua } \\
\text { presença, dirigindo- } \\
\text { se apenas aos } \\
\text { outros }\end{array}$} & $\begin{array}{l}\text { "Eu não me sentia feliz, me sentia maltratado, me sentia renegado, me sentindo isolado porque } \\
\text { não compartilhava dos mesmos valores. Eles (colegas de trabalho) não me chamavam para } \\
\text { almoço, nem nada. Ficavam batendo papo entre si e estavam nem aí se eu estava no assunto } \\
\text { ou não. Já com outras pessoas eles tinham essa preocupação." (E1) }\end{array}$ \\
\hline & $\begin{array}{l}\text { "Tudo deu início quando meu chefe ficou fazendo algumas brincadeiras que eu achava que } \\
\text { eram brincadeiras, só que isso se tornou constante. Ele ficava me zoando na frente de todo } \\
\text { mundo e eu levava na brincadeira, né, até porque todos estavam rindo. Só depois eu fui } \\
\text { perceber que aquele grupo fazia parte do grupo da fofocaiada. Eu ia falar com eles e eles } \\
\text { estavam sempre ocupados pra mim. Aí a coisa se tornou tão doentia e eu fui percebendo que } \\
\text { não era só uma brincadeira, né, que ele estava ali para me humilhar juntamente com a corja." } \\
\text { (E2) }\end{array}$ \\
\hline $\begin{array}{c}\text { Proíbem os colegas } \\
\text { de Ihe falar }\end{array}$ & $\begin{array}{l}\text { "Ela (coordenadora de outra área) proíbe que os colaboradores que atuam na equipe dela } \\
\text { falem comigo ou almocem comigo e, quando almoçam, sofrem retaliação, muita retaliação. Ela } \\
\text { própria falou 'quem está na minha equipe está proibido de falar com uma pessoa que nem a } \\
\text { [Nome do Entrevistado]. Se não vai se ver comigo'." (E21) }\end{array}$ \\
\hline $\begin{array}{l}\text { Já não a deixam } \\
\text { falar com ninguém }\end{array}$ & $\begin{array}{l}\text { "[...] Eu tava na primeira semana de banco, [...] no caixa trabalhando e aí eu precisava que a } \\
\text { gerente passasse um cartão supervisor pra autorizar uma transação, pra autorizar um estorno, } \\
\text { porque eu tinha pago um boleto errado. [...] E aí eu pedi o cartão pra ela, a gerente veio, já } \\
\mathrm{p}^{\star * *},[\ldots] \text { e }[\ldots . .] \text { cheio de cliente sendo atendidos em todos os caixas lá, [...] em todas as } \\
\text { baterias, todo mundo lá, ela chegou atrás de mim e falou 'vem cá, você vai ficar brincando na } \\
\text { minha bateria de caixa ou você vai trabalhar sério? Não tem mais criança aqui, eu não cuido } \\
\text { de criança. Não tem que dar trela pra cliente não'. E aí ficou mó silêncio." (E24) }\end{array}$ \\
\hline $\begin{array}{l}\text { A direção recusa } \\
\text { qualquer pedido de } \\
\text { entrevista }\end{array}$ & $\begin{array}{l}\text { "Minha chefe, desde o princípio, dizia que qualquer crítica que tivéssemos para fazer ou } \\
\text { qualquer coisa que nos deixasse insatisfeita, nós poderíamos falar diretamente com ela, } \\
\text { porque ela prezava pela honestidade e sinceridade. Duas vezes eu falei com ela, duas vezes } \\
\text { eu tomei foras e ela ficou p p }{ }^{* \star *} \text { comigo e isso se refletia no dia a dia do trabalho." (E13) }\end{array}$ \\
\hline
\end{tabular}

Fonte: Autoria própria

\subsubsection{Subcategoria 3: Atentados contra a dignidade}

Tendo o intuito de desqualificar e expor o trabalhador ao ridículo na frente do público, a abordagem de atentados contra a dignidade é empregada. Ela é visível a todos, mas a culpa é sempre atribuída à vítima. Em relação ao grupo, pode-se dizer que a ocorrência dos fatos se dá mais por meio de colegas com inveja do que pela chefia.

O episódio de maior frequência nesta subcategoria foi o elemento em que a vítima é desacreditada diante dos colegas, superiores ou subordinados e que os colegas de trabalho foram os maiores responsáveis pelo acontecimento desse subtópico, assim como Hirigoyen (2015) declarou.

O Quadro 7 a seguir relaciona os elementos com as falas. 
Quadro 7: Atentados contra a dignidade

\begin{tabular}{|c|c|}
\hline Elemento de análise & Exemplos \\
\hline \multirow[t]{2}{*}{$\begin{array}{l}\text { Utilizam insinuações } \\
\text { desdenhosas para } \\
\text { qualificá-la }\end{array}$} & $\begin{array}{l}\text { "Quando eu ia pegar água pra todo mundo eu perguntava quem queria pra poder agilizar a } \\
\text { vida do pessoal lá, né, pra deixar que eles (chefe e colegas de trabalho) não percam tempo e } \\
\text { aí vez ou outra eu acabava esquecendo de perguntar, nisso meu chefe ficava falando alto, } \\
\text { inclusive as outras áreas ouviam, 'aí, você já foi melhor, hein, você pegava água para gente, } \\
\text { hoje em dia está fechando com os errados você não faz mais. Se tornou uma deles' os } \\
\text { errados que ele queria dizer eram umas pessoas que ele não gostava. E claro que todo } \\
\text { mundo ria e dava crédito, porque era engraçado ridicularizar os outros." (E2) }\end{array}$ \\
\hline & $\begin{array}{l}\text { "A assessora do meu chefe me constrangeu por diversas vezes diante de meus colegas se } \\
\text { utilizando de expressões tipicamente machistas para de certa forma me humilhar. Foi ridículo } \\
\text { o jeito dela. Ela ficava falando que eu era muito mulherzinha pra aquela vaga." (E17) }\end{array}$ \\
\hline $\begin{array}{l}\text { Fazem gestos de } \\
\text { desprezo diante dela }\end{array}$ & $\begin{array}{l}\text { "Quando eu avisei aos meus colegas que trabalhavam na mesma área que eu ia sair, com o } \\
\text { meu chefe na sala de reunião, né, a única reação deles foi 'hm, tá bom então', com um tom } \\
\text { de deboche e cara também e percebi que fizeram um gesto com o olho para o meu chefe, } \\
\text { que também devolveu esse gesto." (E2) }\end{array}$ \\
\hline \multirow{7}{*}{$\begin{array}{l}\text { É desacreditada } \\
\text { diante dos colegas, } \\
\text { superiores ou } \\
\text { subordinados }\end{array}$} & $\begin{array}{l}\text { "Em um caso em particular, eu tava conversando com uma outra pessoa da empresa [...] e a } \\
\text { pessoa me perguntou um problema para que nós dois conseguíssemos resolver o problema } \\
\text { juntos. Como eu não tinha muito tempo na empresa, não tinha total conhecimento dos } \\
\text { processos, enfim, de como tudo funcionava, ela me fez uma pergunta e eu resolvi fazer essa } \\
\text { mesma pergunta pro meu chefe pra poder confirmar. Eu recebi a seguinte resposta dele 'você } \\
\text { responda tal coisa pra essa pessoa, porque se você não responder eu vou responder por } \\
\text { você de maneira mal-educada inclusive pra você. Já era pra saber disso'. E naquele } \\
\text { momento eu consegui entender que da parte da minha liderança eu tava sendo um completo } \\
\text { idiota, um completo ignorante por estar fazendo aquela pergunta. Até um colega que era do } \\
\text { mesmo nível da liderança do meu chefe disse pra mim que se eu precisasse de alguém pra ir } \\
\text { no RH dar queixa ele me acompanharia, mas a grande sacanagem é que eu sei que essa } \\
\text { pessoa falou isso em tom de brincadeira, mas a brincadeira que foi feita, foi feita pra perceber } \\
\text { e expor uma coisa que era séria." (E1) }\end{array}$ \\
\hline & $\begin{array}{l}\text { " 'É por isso que falo que você tem que aprender a ser esperta e parar de ser trouxa. Você } \\
\text { não está sendo esperta porque se você fosse você responderia de forma grosseira. Tem que } \\
\text { ser grosseira porque vai ser uma lição pra eles'. E ele falou isso alto diversas vezes e então } \\
\text { outras pessoas ouviram, outras áreas ouviram. Até vieram me perguntar como eu ainda } \\
\text { estava ali. Depois, o pessoal que trabalhava comigo tudo enquanto me chamava de trouxa e } \\
\text { falava 'bem que o teu chefe tinha razão'." (E2) }\end{array}$ \\
\hline & $\begin{array}{l}\text { "Do nada o gerente da loja chega e fala 'nossa, vocês estão muito lerdas' [...], 'Por que que tu } \\
\text { tá enrolando? Já viu o tamanho da fila? Isso é muito fácil de aprender, outra daria conta } \\
\text { rapidinho.' A gente tava pegando em dinheiro e dando troco, mas tinha que ser rápido e se } \\
\text { errasse, você era cobrado na frente de todo mundo. [...] Quando eu falei que estava pedindo } \\
\text { as contas pro meu chefe, ele virou pra mim e falou 'você nunca vai conseguir ser alguém na } \\
\text { vida'. Aquilo me doeu tanto que não tenho palavras para lhe dizer." (E3) }\end{array}$ \\
\hline & $\begin{array}{l}\text { "Eu tinha uma supervisora no trabalho, [...] que fazia questão de enfatizar pra todo mundo } \\
\text { que seu cargo era melhor que dos outros funcionários. [...] Sempre que possível ela jogava } \\
\text { piadas 'eu consigo fazer isso porque eu sou a coordenadora né? Nessa unidade eu faço } \\
\text { todos os trabalhos. Não tenho uma equipe qualificada. Refaça esse trabalho, nem parece que } \\
\text { você ganha tão bem assim' e coisas assim." (E7) }\end{array}$ \\
\hline & $\begin{array}{l}\text { "Ela (chefe) frequentemente dizia que todo mundo era substituível e que se a pessoa erra } \\
\text { muito ela preferia substituir logo por uma outra. Ela mesma já virou pra mim, além de falar } \\
\text { isso, né, falou também que não sabia o porquê de ter me contratado, porque eu não era } \\
\text { capaz e sagaz o suficiente para estar ali. Meus colegas ouviram e ficaram calados." (E16) }\end{array}$ \\
\hline & $\begin{array}{l}\text { "Em algumas reuniões, no meio de todo mundo, onde cada um falava o que fez, ela } \\
\text { perguntava, assim, na frente de todo mundo, 'é, [Nome do Entrevistado], você não fechou tal } \\
\text { seguro, você não fez não sei o que lá', tipo assim, 'ah, a única pessoa que não entregou foi a } \\
\text { [Nome do Entrevistado]'." (E20) }\end{array}$ \\
\hline & $\begin{array}{l}\text { "[...] Eu tô tendo um caso [...] de uma gerente que [...] ela [...] me difamou na frente da } \\
\text { Superintendente e eu questionei ela também na frente da Superintendente. Falei 'olha só, } \\
\text { você foi lá me corrigir e saiu andando. Por que que você não ficou lá e explicou o que que era } \\
\text { ao invés de só me cortar e sair andando?'. Aí ela 'ah, mas você não respondeu certo, falou } \\
\text { errado'. Aí eu 'não falei errado. Se eu tivesse falado errado você vinha aqui e falava o certo. } \\
\text { Você só falou que falei errado e foi embora. Eu achei isso errado de você ter feito isso na } \\
\text { frente da [Nome da Superintendente] e não quero que isso se repita' [...]. De lá pra cá a } \\
\text { menina não falou comigo, tenho certeza que ela tá falando mal de mim aí pelas costas, } \\
\text { porque ela é dessas." (E24) }\end{array}$ \\
\hline
\end{tabular}




\begin{tabular}{|c|c|}
\hline $\begin{array}{l}\text { Atribuem-lhe } \\
\text { problemas } \\
\text { psicológicos }\end{array}$ & $\begin{array}{l}\text { "Então, além de camelo, o apelido que pairava sobre mim era retardado. Diziam (chefes e } \\
\text { colegas de trabalho) que eu não servia pra trabalhar ali, que eu não sabia o que estava } \\
\text { fazendo ali, porque eu era o mais lerdo do grupo pra aprender. Que por isso eu tinha de ser } \\
\text { internado." (E11) }\end{array}$ \\
\hline \multirow{2}{*}{$\begin{array}{l}\text { Zombam de suas } \\
\text { deficiências ou de } \\
\text { seu aspecto físico; é } \\
\text { imitada ou } \\
\text { caricaturada }\end{array}$} & $\begin{array}{l}\text { "No trabalho, eles fazem brincadeiras como, [...] 'pô, cara, você está conseguindo enxergar o } \\
\text { computador aí? Olho fechado e não sei o que'." (E4) }\end{array}$ \\
\hline & $\begin{array}{l}\text { "Em uma época eu tinha cabelo grande e eles (colegas de trabalho) zoavam o meu cabelo, } \\
\text { ficavam me imitando, me chamando de maluco, ficavam dizendo que eu parecia um camelo } \\
\text { por causa do meu corpo e do meu rosto." (E11) }\end{array}$ \\
\hline $\begin{array}{c}\text { Criticam sua vida } \\
\text { privada }\end{array}$ & $\begin{array}{l}\text { "Lá no meu trabalho, não só comigo [...], mas com outras pessoas também acontecem } \\
\text { brincadeiras, deboches. A pessoa, particularmente uma das pessoas (colegas de trabalho), a } \\
\text { principal delas que pratica esse assédio [...] é uma mulher. Ela é uma pessoa extremamente } \\
\text { debochada, ela não sabe ser profissional, não sabe ter ética, então ela invade a sua vida } \\
\text { pessoal, ela debocha de qualquer coisa relacionada à você, seja do seu jeito de ser e da sua } \\
\text { personalidade, das coisas que você faz." (E21) }\end{array}$ \\
\hline $\begin{array}{l}\text { Zombam de suas } \\
\text { origens ou de sua } \\
\text { nacionalidade }\end{array}$ & $\begin{array}{l}\text { "A minha experiência pelo fato de ser asiático, né, eu sofro bastante tipo de assédio, né, que, } \\
\text { principal assédio é sobre a minha etnia. No trabalho, eles fazem brincadeiras como, no } \\
\text { horário de almoço, 'ah, você come barata, você come não sei o que, você come cachorro'." } \\
\text { (E4) }\end{array}$ \\
\hline \multirow[b]{3}{*}{$\begin{array}{l}\text { É injuriada com } \\
\text { termos obscenos ou } \\
\text { degradantes }\end{array}$} & $\begin{array}{l}\text { "Diversas vezes eu tive que ouvir falas desrespeitosas, do tipo 'que estúpido', me diminuindo } \\
\text { e que eu também sentia como se houvesse uma criação de um clima de insegurança, onde a } \\
\text { pessoa poderia não tá falando nada, mas tinha um clima tenso. A pessoa não poderia não } \\
\text { estar fazendo nada exatamente aquele momento, mas existia uma tensão." (E1) }\end{array}$ \\
\hline & $\begin{array}{l}\text { " (colegas de trabalho) sempre me chamando de lerda, que eu não ia conseguir ir pra canto } \\
\text { nenhum com aquilo. Falava até que tinha nojo porque eu suava muito." (E3) }\end{array}$ \\
\hline & $\begin{array}{l}\text { "Outras pessoas já me contaram que ela e o Coordenador de outra área se juntam na frente } \\
\text { da TV Corporativa pra poder ficar achando erro e ficar me zoando ou até mesmo convidando } \\
\text { alguém da equipe pra mesa dela pra zombar de algum comunicado que eu postei. 'Olha lá a } \\
\text { sem noção postando no Linkedln da empresa, olha lá o que a sem noção postou na Intranet. } \\
\text { Ela errou isso, ela errou aquilo' e nunca passa despercebido. Claro, ficam jogando todo } \\
\text { trabalho para a equipe fazer [...], aí tem tempo pra ficar cuidando da vida dos outros. [...] É } \\
\text { todo dia, todo dia é um inferno novo pra enfrentar, é uma situação nova, é um leão pra matar. } \\
\text { Todo dia tem uma coisa, não é uma coisa pontual. Acontece todo santo dia." (E21) }\end{array}$ \\
\hline
\end{tabular}

Fonte: Autoria própria

\subsubsection{Subcategoria 4: Violência verbal, física ou sexual}

Nessa subcategoria, o assédio já ocorre de maneira prolongada em termos históricos e está exposto a todos, sendo promovido pelo superior hierárquico e pelos colegas de trabalho. A essa altura, a vítima possui um estereótipo claro e quem do grupo manifestar piedade, acaba sofrendo retaliações.

Dentre os elementos destacados, o de falar com gritos se destacou. Ademais, os eventos foram majoritariamente praticados pelos superiores hierárquicos. Apenas o relato da E6 que contou com ambos agentes: chefe e colega de trabalho.

Nesse estágio, o assédio moral já está claramente visível para todos e essa afirmação vai de encontro com todos os relatos dos entrevistados, se tornando, desta forma, palpável e até tangível.

Os relatos das falas dos entrevistados encontram-se no Quadro 8. 


\section{Quadro 8: Violência verbal, física ou sexual}

\begin{tabular}{|c|c|}
\hline Elemento de análise & Exemplos \\
\hline \multirow{5}{*}{$\begin{array}{c}\text { Falam com ela aos } \\
\text { gritos }\end{array}$} & $\begin{array}{l}\text { "Eu tive uma chefe que gostava muito de gritar. Qualquer coisinha que você não fizesse do jeito } \\
\text { que ela quisesse exatamente era um motivo pra tomar uma bronca. Mas não era uma bronca } \\
\text { qualquer, uma chamada, assim. Era uma bronca daquelas que a área inteira escuta, dela estar } \\
\text { em pé, gritando, olhando pra você e todo mundo para o que tá fazendo pra olhar pra você." } \\
\text { (E16) }\end{array}$ \\
\hline & $\begin{array}{l}\text { "Eu cheguei na empresa e esse meu gerente se achou no direito de gritar e jogar toda culpa, } \\
\text { [...] porque o jogo [...] acabou não sendo coberto, [...] pra cima de mim, porque ele achava que } \\
\text { [...] eu sabia da questão (demissão de um integrante da equipe), [...] que eu tinha sido avisado } \\
\text { e eu só fiquei sabendo no momento que ele me ligou de manhã. Tanto que depois [...], eu não } \\
\text { sei o que que houve, se houve uma conversa, o que que aconteceu, que ele veio pra mim, não } \\
\text { em um tom de desculpa, né, porque ele não assumiu que errou, mas ele falou que realmente } \\
\text { eu não tava escalado, que aquele jogo ali não era pra eu ter feito, mas não pediu desculpas. } \\
\text { [...] Eu fiquei tão acostumado com esse tipo de situação, que já era normal pra mim." (E19) }\end{array}$ \\
\hline & $\begin{array}{l}\text { "Também tinha questões da gente trabalhar na agência e o telefone só podia tocar } 3 \text { toques, } \\
\text { que se a gente atendesse depois dos } 3 \text { toques isso era ruim. Então, muitas vezes eu tava } \\
\text { atendendo, porque lá a gente atendia cliente presencial, a gente atendia cliente por telefone, } \\
\text { por e-mail, enfim, e aí muitas vezes eu tava atendendo cliente e o telefone tocava duas vezes, } \\
\text { três vezes e ela (chefe) gritava na agência, assim, '[Nome do Entrevistado], [Nome do Colega } \\
\text { de Trabalho do Entrevistado], sei lá quem', mas com um tom bem grosso, sabe? Ela ficava } \\
\text { gritando pra que a gente atendesse o telefone e aí ela mesma não atendia. [...] Ela é tipo um } \\
\text { jeito muito general de fazer as coisas." (E20) }\end{array}$ \\
\hline & $\begin{array}{l}\text { "Uma vez que eu tinha que fazer uma divulgação e aí eu tinha um monte de outras coisas pra } \\
\text { fazer e [...] era sexta-feira e [...] seria enforcado na segunda, porque terça era feriado. E aí a } \\
\text { minha gerente ela começou a gritar no meio do escritório de que ah, se eu queria que tivesse } \\
\text { feriado que nem todo mundo eu tinha que divulgar aquilo ali até tal hora e eu não poderia sair } \\
\text { no horário que eu tinha que sair pra ir pra aula, porque eu tinha que divulgar aquilo e eu tinha } \\
\text { que dar o meu jeito, porque senão eu tinha que ir trabalhar sozinha na segunda, porque todo } \\
\text { mundo tinha sido, segundo ela, capaz o suficiente de fazer tudo o que tinha que fazer no } \\
\text { horário de trabalho, portanto não ia precisar ir na segunda-feira, mas que eu precisaria se eu } \\
\text { não divulgasse isso. [...] Outro caso foi no passado que ela teve uma crise e aí ela saiu } \\
\text { descontando a raiva dela em todo mundo." (E23) }\end{array}$ \\
\hline & $\begin{array}{l}\text { "No banco rola uma experiência muito tranquila de assédio. [...] O tapinha nas costas, o } \\
\text { reconhecimento, é no sapatinho. É ali no e-mail, é na parada pra uma foto [...]. Agora, a } \\
\text { chamada, o esporro, o berro, é na frente de geral. É durante uma reunião, é durante uma } \\
\text { conferência [...]. Mais uma experiência que eu tenho no banco e que é muito comum de [...] } \\
\text { chegarem e falarem assim 'pô, final do mês as outras agências estão batendo tudo, todas as } \\
\text { metas, e a gente não tá.' [...] Onde eu trabalho tem } 31 \text { agências. É claro que tem algumas } \\
\text { batendo e outras não. Mas aí a gente toma esporro mesmo, porque não tá batendo." (E24) }\end{array}$ \\
\hline $\begin{array}{l}\text { Invadem sua vida } \\
\text { privada com } \\
\text { ligações telefônicas } \\
\text { ou cartas }\end{array}$ & $\begin{array}{l}\text { "Eu não tava escalado [...] e havia um jogo no sábado, no qual era de manhã, né, era um jogo } \\
\text { que ia acontecer acho que 10, } 11 \text { horas [...] e eu tava escalado pra chegar pela tarde. [...] } \\
\text { Naquela semana tinha entrado um estagiário novo no time pra tentar me ajudar e o menino } \\
\text { entrou na segunda e saiu na sexta, [...] e aí chegou meu gerente no sábado de manhã, } \\
\text { bastante cedo, me ligando desesperado, perguntando onde é que eu tava, porque eu tinha que } \\
\text { cobrir o jogo, já que o outro rapaz não ia mais pra TV. Sendo que eu não fui informado de } \\
\text { nada. [...] Isso aconteceu várias vezes." (E19) }\end{array}$ \\
\hline $\begin{array}{l}\text { É assediada ou } \\
\text { agredida } \\
\text { sexualmente } \\
\text { (gestos ou } \\
\text { propostas) }\end{array}$ & 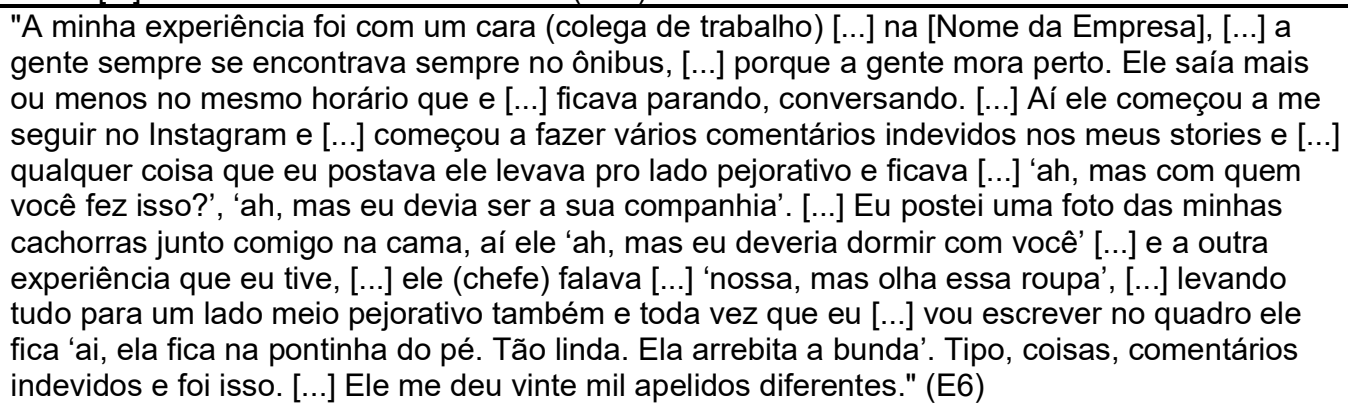 \\
\hline
\end{tabular}




\begin{tabular}{|c|c|}
\hline \multirow{2}{*}{$\begin{array}{l}\text { Continuação } \\
\text { É assediada ou } \\
\text { agredida } \\
\text { sexualmente } \\
\text { (gestos ou } \\
\text { propostas) }\end{array}$} & $\begin{array}{l}\text { "Certa vez fui chamado à sala de reuniões da empresa para uma conversa e depois de falar de } \\
\text { alguns assuntos triviais e ela (chefe) declarar que confiava em mim, mas que gostaria de uma } \\
\text { prova para confiar ainda mais. [...] Ela me solicitou ver as conversas registradas no meu celular } \\
\text { pra ver seu havia mantido contato com uma ex-integrante da empresa que tinha se tornado um } \\
\text { desafeto pra ela e de outros diretores e gerentes da empresa. Só um detalhe importante pra } \\
\text { você entender: essa solicitação também foi feita a outro colaborador que acabou que recusou o } \\
\text { pedido e foi mandado embora por isso." (E17) }\end{array}$ \\
\hline & $\begin{array}{l}\text { "E aí teve algumas cenas [...] que eu tava atendendo o cliente na mesa, resolvendo algum } \\
\text { problema dele, [...] o telefone tava tocando, ela (chefe) levantava, se posicionava na frente da } \\
\text { minha mesa que dava pra ver, atrás do cliente, e falava assim 'atende o telefone'. Aí eu olhava } \\
\text { pra ela e falava assim 'não tem como, eu tô atendendo o cliente'. Aí depois quando o cliente ia } \\
\text { embora ela me chamava pra me dar esporro, falando que eu [...] tinha que atender o telefone, } \\
\text { mesmo estando com o cliente, que eu tinha que fazer tudo ao mesmo tempo. Eu tinha que dar } \\
\text { conta, no caso. [...] Isso aconteceu muitas vezes, ou então acontecia de às vezes eu estar na } \\
\text { recepção com fila de cliente, atendendo cliente presencial, [...] atendendo a demanda dele, } \\
\text { uma fila enorme atrás, o telefone tocava e a gente tinha que atender e não necessariamente } \\
\text { uma linha, porque tocava nas duas linhas. Então você tinha que atender o cliente e atender } \\
\text { duas linhas. E muitas vezes ela chegava atrás da gente e ficava olhando pra nossa cara até a } \\
\text { gente puxar a segunda linha." (E20) }\end{array}$ \\
\hline \multirow[b]{2}{*}{$\begin{array}{l}\text { Não levam em conta } \\
\text { seus problemas de } \\
\text { saúde }\end{array}$} & $\begin{array}{l}\text { "Eu tinha tendinite já nessa época, porque ficava lidando com coisas pesadas e tal. O médico já } \\
\text { tinha diagnosticado e tudo mais, só que ela (chefe) sempre ficava botando eu pra fazer as } \\
\text { coisas com peso. Eu falando que tava doendo e ela me ignorando." (E9) }\end{array}$ \\
\hline & $\begin{array}{l}\text { "O que foi mais marcante pra mim foi no período que tive depressão. [...] Devido [...] a } \\
\text { dificuldade de acordar e levantar, eu chegava constantemente atrasada, todos os dias. A minha } \\
\text { chefe estava de férias nesse período e deixou a subchefe encarregada de tomar conta dos } \\
\text { horários. E, assim, embora eu chegasse sempre atrasada, não por vontade própria, mas } \\
\text { porque eu realmente não conseguia sabe? Mesmo assim o meu atraso não era significativo. No } \\
\text { máximo, chegava com trinta minutos de atraso, [...] e como tinha uma hora de almoço, eu } \\
\text { sempre descontava. Então se eu chegava } 15 \text { minutos atrasada, eu tirava apenas } 45 \text { minutos de } \\
\text { almoço, sempre tentando cumprir com o meu horário para não ter problema. Mas aí, como eu } \\
\text { bato ponto, meus atrasos sempre ficaram marcados. Aí pedi um atestado à minha psicóloga } \\
\text { pra quando minha chefe retornasse de férias, eu pudesse apresentá-lo e justificar os meus } \\
\text { atrasos, esperando que ela fosse entender, né? Nisso eu não só descobri por acaso que minha } \\
\text { subchefe havia feito um relatório com as minhas desculpas, entre aspas, por chegar atrasada, } \\
\text { como quando fui apresentar o atestado para minha chefe, que nele constava que eu tinha } \\
\text { depressão e ansiedade [...], minha chefe foi extremamente insensível, falando várias coisas } \\
\text { agressivas como 'parece que você quer ser demitida', 'não consigo entender, porque você tem } \\
\text { contas a pagar'. Eu comecei a chorar de raiva/tristeza, um misto de sentimentos que nem dá } \\
\text { pra explicar." (E13) }\end{array}$ \\
\hline
\end{tabular}

Fonte: Autoria própria

\subsection{Categoria 2 - Abuso de poder}

A segunda categoria, denominada de abuso de poder, relaciona os itens que emergiram do campo e que não obtiveram combinação dentro da listagem de atitudes hostis de Hirigoyen (2015). São eles: ameaças à estabilidade no trabalho, vigia excessiva, discriminação de gênero, retirada de benefícios adquiridos e imposição de poder.

Percebe-se que no abuso de poder, a ameaça à estabilidade no trabalho se mostrou mais comum. Outrossim, nesta ameaça, verificam-se situações praticadas pelo superior hierárquico e colegas de trabalho, sendo a maioria pelo primeiro.

O Quadro 9 ilustra os relatos das questões abordadas. 


\section{Quadro 9: Subcategorias emergidas do campo}

\begin{tabular}{|c|c|}
\hline $\begin{array}{l}\text { Elemento de } \\
\text { análise }\end{array}$ & Exemplos \\
\hline \multirow{5}{*}{$\begin{array}{l}\text { Ameaças à } \\
\text { estabilidade } \\
\text { no trabalho }\end{array}$} & $\begin{array}{l}\text { "Eu sei que no final desse primeiro dia essa menina (colega de trabalho) virou pra mim e falou 'Se } \\
\text { continuar assim vai acabar saindo. Tem que pegar o ritmo logo ou senão não vou te ensinar. Não vou } \\
\text { tomar a culpa por você'." (E3) }\end{array}$ \\
\hline & $\begin{array}{l}\text { "[...] Quando fui apresentar o atestado para minha chefe, que nele constava que eu tinha depressão e } \\
\text { ansiedade [...], minha chefe foi extremamente insensível, falando várias coisas agressivas como } \\
\text { 'parece que você quer ser demitida', 'não consigo entender, porque você tem contas a pagar'. Eu } \\
\text { comecei a chorar de raiva/tristeza, um misto de sentimentos que nem dá pra explicar." (E13) }\end{array}$ \\
\hline & 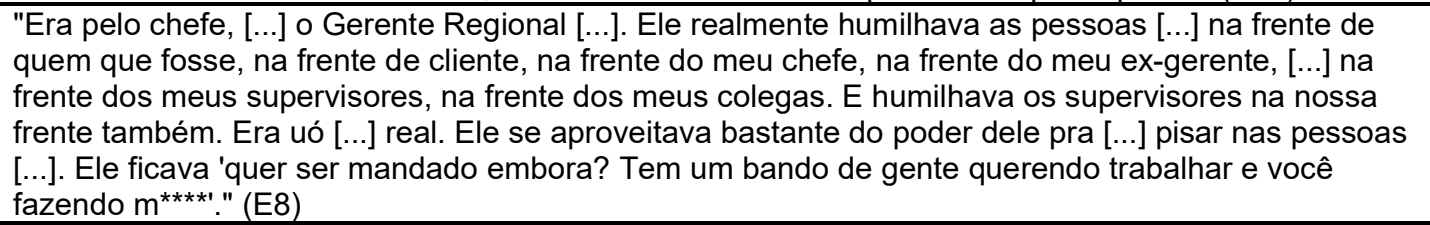 \\
\hline & $\begin{array}{l}\text { "O gerente da área (automobilismo) me chamou duas vezes pra trabalhar lá e o meu gerente da } \\
\text { editoria Nordeste disse que isso não seria possível, porque [...] a editoria só contava comigo e que se } \\
\text { tivesse que demitir pessoas da empresa, a primeira editoria que seria cortada era a de automobilismo } \\
\text { [...]. E que era melhor eu ficar onde eu tava, pra eu não correr esse risco. [...] E aí começou-se a falar } \\
\text { em demissão, [...] começou-se a falar em 'vai ficar sem emprego'." (E19) }\end{array}$ \\
\hline & $\begin{array}{l}\text { "Ela (coordenadora de outra área) já tentou cortar a minha cabeça com o Diretor de RH. Eu fiquei um } \\
\text { mês esperando a decisão dele se eu ia ser demitida ou não. Ele me contou isso, [...] por isso que eu } \\
\text { sei. Mas foi graças a ela. Ele próprio falou também depois [...] que ela ficava fazendo a minha caveira } \\
\text { e de outras pessoas pra poder ir embora." (E21) }\end{array}$ \\
\hline \multirow{3}{*}{$\begin{array}{l}\text { Vigia } \\
\text { excessiva }\end{array}$} & $\begin{array}{l}\text { "Quando eu fazia hora extra, ela (chefe encarregada) chamava uma pessoa que se aliou a ela, uma } \\
\text { novata e ficava interrogando o que eu tinha feito. Se eu saísse pra ir ao banheiro ou beber água, com } \\
\text { as colegas ela não reclamava, mas quando era eu ela sempre perguntava 'tava aonde?'." (E9) }\end{array}$ \\
\hline & 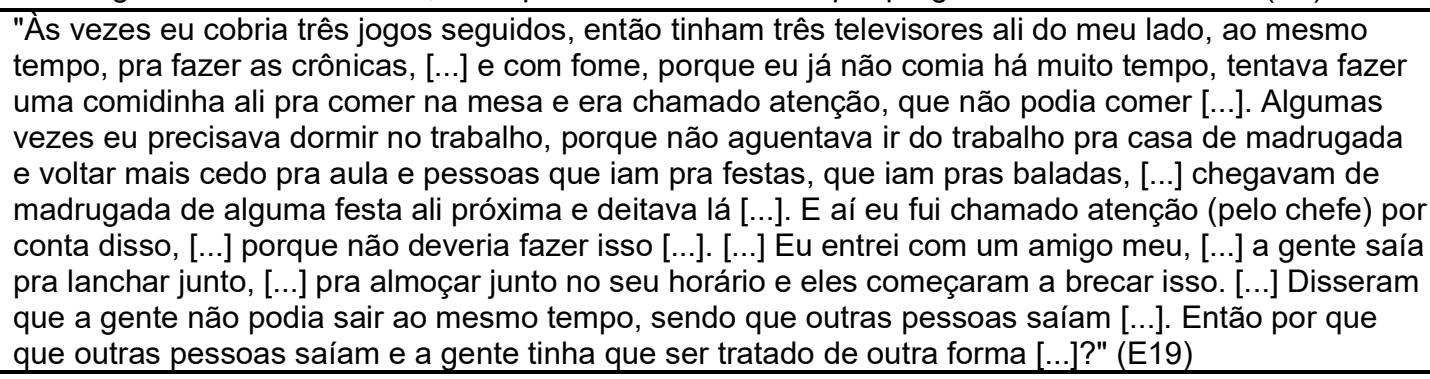 \\
\hline & $\begin{array}{l}\text { "Ela (chefe) vinha ver o que tava fazendo no computador, ficava te questionando, ficava me cobrando } \\
\text { coisas que era pro gerente fazer e eu não era gerente. Então,[...] eu tinha que abrir [...] dez contas, } \\
\text { então aí se um dia ela pedisse pra eu focar em abrir as contas, então ela ficava de } 5 \text { em } 5 \text { minutos } \\
\text { perguntando 'quantas contas você abriu?', 'você abriu agora?', 'você tá abrindo agora?', mandava } \\
\text { mensagem no WhatsApp [...]. 'O que que você tá fazendo?'. Enfim, era uma parada } \\
\text { enlouquecedora." (E20) }\end{array}$ \\
\hline \multirow{2}{*}{$\begin{array}{l}\text { Discriminação } \\
\text { de gênero }\end{array}$} & $\begin{array}{l}\text { "Pode ser coisa da minha cabeça, mas eu tinha a ligeira impressão de que isso acontecia mais com } \\
\text { as mulheres. Pelo menos via que com os homens ele (chefe) era mais tranquilo." (E3) }\end{array}$ \\
\hline & $\begin{array}{l}\text { "Eu sofria por ser homossexual. Dava pra ver na cara dele a desaprovação por mim. Até porque ele } \\
\text { ficava me tacando de coisa de trabalho pra fazer também, enquanto que os outros ficavam de boa, } \\
\text { tipo assim, sem fazer nada ou quase nada." (E8) }\end{array}$ \\
\hline $\begin{array}{l}\text { Retirar os } \\
\text { benefícios } \\
\text { adquiridos }\end{array}$ & $\begin{array}{l}\text { "Depois de 10, } 11 \text { horas da noite, [...] eu deveria pegar um táxi. [...] Eu morava [...] numa favela [...] e } \\
\text { como eu saía muito tarde eu não tinha condição, não tinha mais trem pra pegar, [...] eu tinha que } \\
\text { fazer o seguinte: eu tinha que pegar um ônibus de Botafogo pra Central, da Central pra Madureira e } \\
\text { de Madureira pra Marechal Hermes, onde eu morava. [...] Era acordado que todo dia que eu ficasse } \\
\text { muito tarde, eu deveria ter um voucher [...] de táxi e chegou um certo momento que não deram mais } \\
{[\ldots] .[\ldots] \text { Eu fiquei naquela situação de sair } 2 \mathrm{~h}, 3 \mathrm{~h} \text { da manhã do trabalho pra chegar em casa e ter que }} \\
\text { tá às } 7 \mathrm{~h} \text { na faculdade e o que me foi passado (pelo chefe) é que havia um superior que precisava do } \\
\text { voucher e que a empresa não ia cobrir mais aquela situação pra mim, [...] do táxi." (E19) }\end{array}$ \\
\hline $\begin{array}{l}\text { Imposição de } \\
\text { poder }\end{array}$ & $\begin{array}{l}\text { "O tom dela (coordenadora de outra área) é extremamente agressivo. Mesmo não sendo da área, ela } \\
\text { acha que pode te dar ordens e se você não acata o que ela manda, você sofre retaliação, [...] você é } \\
\text { excluído da panela, você passa por situações de deboche. [...] Conversinhas, comentários, ela fala } \\
\text { pelas costas, fala mal do seu trabalho, cria situações para prejudicar o seu trabalho, passa por cima } \\
\text { da sua autoridade. No caso eu tô à frente de duas áreas [...] e ela tenta a qualquer custo passar por } \\
\text { cima da minha autoridade, ela cria situações constrangedoras o tempo todo." (E21) }\end{array}$ \\
\hline
\end{tabular}




\subsection{Consequências do assédio moral}

Nesta seção, os entrevistados relataram seus sentimentos, sintomas e como consequências físicas, psicológicas e/ou comportamentais do assédio que sofreram.

Desta forma, seus relatos foram comparados com as consequências apontadas pela FIOCRUZ (2014), devido ao sofrimento passado durante o evento de assédio moral no trabalho, ilustradas no Quadro 10.

\section{Quadro 10: Consequências do Assédio Moral}

\begin{tabular}{|c|c|c|}
\hline Psicopatológica & Psicossomáticas & Comportamental \\
\hline$\perp$ & P & \\
\hline$\square$ Ansiedade & $\square$ Hipertensão arterial & $\square \begin{array}{l}\text { Agressividade contra si e contra } \\
\text { os outros }\end{array}$ \\
\hline Apatia & $\square$ Ataques de asma & $\square \begin{array}{l}\text { Aumento do consumo de álcool } \\
\text { e drogas }\end{array}$ \\
\hline Insegurança & $\square$ Taquicardia & 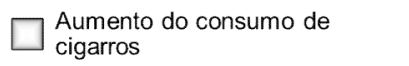 \\
\hline$\square$ Depressão & $\square$ Doenças coronarianas & $\square$ Disfunções sexuais \\
\hline$\square$ Melancolia & $\square$ Dermatites & $\square$ Isolamento social \\
\hline$\square$ Irritação & $\square$ Cefaleia & $\square$ Desordens de apetite \\
\hline$\square$ Insônia & $\square$ Dores musculares & \\
\hline$\square$ Mudança de humor & $\square$ Gastrite & \\
\hline \multicolumn{3}{|l|}{$\square$ Pânico e fobias } \\
\hline$\square$ Pesadelos & & \\
\hline
\end{tabular}

Fonte: FIOCRUZ (2014) 
Dentre os três itens presentes no grupo, as doenças psicopatológicas foram as que mais se destacaram e, dentro dela, os entrevistados relataram sofrer mais com ansiedade, irritação, mudança de humor, apatia e insegurança e menos com pânico e fobias.

Em segundo lugar, foram mencionadas as doenças psicossomáticas, e os voluntários relataram sentir cefaleia, dores musculares, taquicardia e gastrite no decorrer do fenômeno.

Por fim, em relação aos impactos comportamentais, o isolamento social, desordens de apetite, agressividade contra si e contra os outros, aumento do consumo de álcool e drogas e disfunções sexuais foram mais citados como decorrência. 


\section{Considerações Finais}

Os objetivos originadores do presente estudo foram compreender e levantar os relatos do assédio moral no trabalho e os impactos decorrentes da situação. Por se tratar de um assunto com definição pouco conhecida no cotidiano do trabalho, identificou-se a necessidade por maior esclarecimento nas empresas, o que originou a motivação de investigar a percepção das pessoas que afirmaram ter passado pelo caso de fato.

Com o intuito de abordar esta problemática, empregados de nível operacional e estagiários de empresas privadas localizadas no Estado do Rio de Janeiro de diversas organizações, setores e tamanhos distintos foram entrevistados. O requisito foi de ter passado por no mínimo três meses durante os últimos seis anos.

Constatou-se uma falta de clareza acerca do assunto, não somente do significado em sua completude, mas, do mesmo modo, da importância da discussão do tema, a fim de se evitar a propagação deste.

Os resultados mostraram que grande parte dos entrevistados de fato enfrentou o fenômeno do assédio moral e todos destacaram pelo menos uma consequência física, psicológica ou comportamental em decorrência do episódio enfrentado. Dentre os desfechos, destacaram-se: a não transferência das informações úteis para a realização de tarefas; crítica do trabalho de forma injusta e exagerada; superiores hierárquicos ou colegas não dialogarem com a vítima; ignorarem a sua presença, dirigindo-se apenas aos outros colaboradores; a vítima é desacreditada diante dos colegas, superiores ou subordinados; falar aos gritos; e a ameaça à estabilidade no trabalho.

As consequências do assédio moral mais identificadas pelos entrevistados foram: ansiedade; irritação; mudança de humor; apatia; insegurança; cefaleia; dores musculares; taquicardia; gastrite; isolamento social; desordens de apetite; agressividade contra si e contra os outros; aumento do consumo de álcool e drogas; e disfunções sexuais.

Como a análise focou apenas nos cargos operacionais e nos estagiários de empresas privadas, sugere-se que, para os trabalhos seguintes, sejam 
examinadas demais posições hierárquicas das organizações, visando a complementariedade de ideias, críticas e investigações efetuadas neste estudo.

É de grande relevância as pessoas obterem o conhecimento acerca do tema para acionar os seus direitos, da mesma forma que as empresas possuam ciência do quão tóxico e prejudicial é o assédio, conforme comprovado neste trabalho.

Recomenda-se, também, que haja a comparação da taxa de ocorrência do assédio moral em empresas com campanhas contra o fenômeno versus as organizações que não se preocupam com essa questão, além de investigar a pesquisa através do acontecimento devido a escolha da orientação sexual, por pessoas de diferentes classes sociais ou etnia, gênero, estilos de liderança que amplificam a presença desta situação, a influência da cultura organizacional para a manifestação do evento, setores da indústria que mais apresentam ocorrência e impactos na marca. 


\section{Referências Bibliográficas}

AGUIAR, M. Assédio moral: problema antigo, interesse recente. Repositório UFSC, Santa Catarina, 2008.

BARIFOUSE, R. Metade dos brasileiros já sofreu assédio no trabalho, aponta pesquisa. São Paulo, 2015. Disponível em: < https://www.bbc.com/portuguese/noticias/2015/06/150610_assedio_trabalho_pes quisa_rb >. Acesso em: junho de 2018.

BARRETO, M. Assédio moral: ato deliberado de humilhação ou uma "política da empresa" para livrar-se de trabalhadores indesejados. Revista Cremesp, São Paulo, 2002.

BARRETO, M. Violência, saúde e trabalho: uma jornada de humilhações. São Paulo: PUC - SP, 2006.

BARROS, A. Curso de Direito do Trabalho. 5a ed. São Paulo: LTr, 2009.

BEZERRA, L.; MARQUES, H. Assédio Moral nas relações de trabalho. Ceará: Universidade Estadual Vale do Acaraú, 2013.

CAVALCANTE, J.; NETO, F. Manual de Direito do Trabalho. Atlas, 2017.

COSTA, l; et al. Produção científica acerca de assédio moral em dissertações e teses no cenário brasileiro. Rev. esc. enferm. USP, São Paulo , v. 49, n. 2, p. 0267-0276, Abril, 2015. Disponível em: $<$ http://www.scielo.br/scielo.php?script=sci_arttext\&pid=S0080$62342015000200267 \&$ Ing=en\&nrm=iso >. Acesso em: maio de 2019.

FABRÍCIO, E. Revisão bibliográfica sobre assédio moral no trabalho: estado da arte da pesquisa brasileira. Brasília: UniCEUB, 2012. 
FERREIRA, H. D. B. Assédio moral nas relações de trabalho. São Paulo: Russel, 2004.

FLEURY, M. T.; FISCHER, R. M. Cultura e poder nas organizações. São Paulo: Atlas, 1989.

FLEURY, R.; et al. $\mathrm{O}$ ABC da Violência contra a Mulher no Trabalho. Ministério Público do Trabalho. Disponível em: <https://mpt.mp.br/pgt/publicacoes/cartilhas/copy_of_o-abc-da-violencia-contraa-mulher-no-trabalho/@@download/arquivo_pdf> Acesso em: maio de 2019.

FONSECA, R. Assédio moral: breves notas. Revista LTr, São Paulo, v. 71, p. 134, 2007.

FONSECA, R. Saúde mental para e pelo trabalho. Revista LTr, São Paulo, v. 67, n. 6, p. 670-679, jun. 2003.

FUNDAÇÃO OSWALDO CRUZ (FIOCRUZ). Assédio moral e sexual no trabalho. Disponível em: <http://www.far.fiocruz.br/wpcontent/uploads/2018/07/Cartilha_assedio_moral_e_sexual.pdf>. Acesso em: junho de 2018.

FREITAS, M. E. Quem paga a conta do Assédio Moral? Revista de Administração de Empresas, São Paulo, v. 6, n. 1, jan./ jun. 2007.

GIL, A. Métodos e Técnicas de Pesquisa Social. 6ª Ed. São Paulo: Atlas, 2011.

GUEDES, M. N. Assédio moral e responsabilidade das organizações com os direitos fundamentais dos trabalhadores. Revista Amatra II, ano IV, n.10, dez., 2003. Disponível em:< http://www.assediomoral.org/site/biblio/MD_01.php>. Acesso em junho de 2018.

GUEDES, M. N. Terror psicológico no trabalho. 3. ed. São Paulo: LTr, 2008. 
HELOANI, J. R. Assédio Moral - Um ensaio sobre a expropriação da dignidade no trabalho. Revista de Administração de Empresas, São Paulo, v. 3, n. 1, jan./ jun. 2004.

HIRIGOYEN, M. F. Assédio moral: a violência perversa no cotidiano. Rio de Janeiro: Bertrand Brasil, 2008.

HIRIGOYEN, M. F. Mal-estar no trabalho: redefinindo assédio moral. Rio de Janeiro: Bertrand, 2015.

HOBSBAWM, J. A Era das Revoluções 1789-1848. Rio de Janeiro: Paz e Terra, 2014.

JUSBRASIL. Judiciário do Tribunal Regional do Trabalho da $21^{\text {a }}$ Região (TRT-21). Disponível em: <https://www.jusbrasil.com.br/diarios/96619797/trt-21judiciario-27-07-2015-pg-132>. Acesso em: junho de 2018.

LEYMANN, H.: The mobbing encyclopaedia. Suécia, 2000. Disponível em: $<$ www.leymann.se>. Acesso em: junho de 2018.

MARTINS, S. Assédio moral no emprego. São Paulo: Atlas, 2012.

MENEZES, C. A. C. Assédio moral e seus efeitos jurídicos. Justiça do Trabalho. Porto Alegre, a. 21, n. 242, p. 7-21, 2004.

MILES, M.; HUBERMAN, M. Qualitative Data Analysis: An Expanded Sourcebook. 2 ed. Londres: Sage, 1994

OLIVEIRA, E. Assédio Moral: sujeitos, danos à saúde e legislação. São Paulo: Revista de Direito do Trabalho, 2004.

OLIVEIRA, E. S. Assédio moral: sujeitos, danos à saúde e legislação. Revista eletrônica do Tribunal Regional do Trabalho da $9^{a}$ Região, Curitiba, PR, v. 2, n. $16, \quad$ p. 128-147, mar. 2013. Disponível em: <https://hdl.handle.net/20.500.12178/95638>. Acesso em: junho de 2018. 
PIÑUEL, I; ZABALA, A. Mobbing: como sobreviver ao assédio psicológico no trabalho. São Paulo: Loyola, 2003.

PLANALTO. Consolidação das Leis do Trabalho. Disponível em: < http://www.planalto.gov.br/ccivil_03/decreto-lei/del5452.htm>. Acesso em: junho de 2018.

PLANALTO. Lei de Crimes Sexuais. Disponível em: < http://www.planalto.gov.br/ccivil_03/_Ato2007-2010/2009/Lei/L12015.htm>. Acesso em: junho de 2019.

PRATA, M. Anatomia do assédio moral no trabalho: uma abordagem transdisciplinar. São Paulo: LTR, 2008.

SANTOS, A. Assédio Sexual Nas Relações Trabalhistas e Estatutárias. 2 ed. Rio de Janeiro: Forense, 2002.

TOLFO, S. R.; SILVA, N.; KRAWULSKI, E. Assédio moral no trabalho: interface com a cultura organizacional e a gestão de pessoas em organizações públicas. Assédio Moral em organizações públicas e a $(\operatorname{Re})$ Ação dos Sindicatos. CRV, Curitiba, 2015, $1^{\text {a }}$ ed, v.1, p. 99-118.

TORRETA, L.; NÓBREGA, C. Assédio Moral: Uma Forma Contemporânea de Desagregação Ética-Laboral. Centro Universitário Salesiano de São Paulo, São Paulo, 2012.

VENOSA, S. Direito Civil - Responsabilidade Civil. 16ª Ed. São Paulo: Atlas, 2016.

VERGARA, S. Projetos e Relatórios de Pesquisa em Administração. $4^{\mathrm{a}}$ Ed. São Paulo, Altas, 2003.

ZANETTI, R. E-Book: Assédio Moral no Trabalho. Conteúdo Jurídico, BrasíliaDF, $2010 . \quad$ Disponível em: <http://www.conteudojuridico.com.br/?artigos\&ver=5.22743\&seo=1>. Acesso em: junho de 2018. 
ZIKMUND, W.; BABIN, B. Princípios da Pesquisa de Marketing. ${ }^{a}$ Ed. São Paulo: Cengage Learning, 2011.

ZIMMERMANN, S. M.; SANTOS, T. C. D. R.; LIMA, W. C. M. O assédio Moral e mundo do trabalho. Ministério Público do Trabalho/ 12ª Região. 2002. 


\section{Anexo}

\subsection{Roteiro da Entrevista}

1. Na sua opinião, o que é assédio moral?

2. Você pode me contar a sua experiência?

3. Quando você percebeu que era assédio?

4. O que você fez a respeito?

5. Como aconteceu depois?

6. Houve alguma ação dos colegas, empresa ou sindicato? Se sim, quais?

7. Há algo a mais que você queira acrescentar?

8. Nessa parte eu irei citar as consequências psicológicas e comportamentais e peço para que você indique qual ou quais ocorreram na sua vivência: 


\begin{tabular}{|c|c|c|}
\hline Psicopatológica & Psicossomáticas & Comportamental \\
\hline$\square$ & $\square$ & $\square$ \\
\hline$\square$ Ansiedade & $\square$ Hipertensão arterial & $\begin{array}{l}\square \text { Agressividade contra si e contra } \\
\text { os outros }\end{array}$ \\
\hline$\square$ Apatia & $\square$ Ataques de asma & $\square$ e drogas \\
\hline$\square$ Insegurança & $\square$ Taquicardia & $\square$ cigarros \\
\hline$\square$ Depressão & $\square$ Doenças coronarianas & $\square$ Disfunções sexuais \\
\hline$\square$ Melancolia & $\square$ Dermatites & $\square$ Isolamento social \\
\hline$\square$ Irritação & $\square$ Cefaleia & $\square$ Desordens de apetite \\
\hline$\square$ Insônia & $\square$ Dores musculares & \\
\hline$\square$ Mudança de humor & $\square$ Gastrite & \\
\hline \multicolumn{3}{|l|}{$\square$ Pânico e fobias } \\
\hline$\square$ Pesadelos & & \\
\hline
\end{tabular}

Outro:

9. Idade:

10. Sexo:
( ) Feminino
( ) Masculino
( ) Outro:

11. Etnia:

( ) Branco

( ) Negro

( ) Pardo

( ) Amarelo

( ) Outro:

12. Estado Civil:

( ) Solteiro

( ) Casado

( ) União Estável

( ) Outro:

13. Escolaridade: 
14. Profissão no momento do ocorrido:

15. Tipo de contrato:
( ) CLT
( ) Temporário
( ) Outro:

16. Você ainda está trabalhando nessa empresa?
( ) Sim
( ) Não

17. A empresa possui/possuía ações contra assédio moral?

( ) $\operatorname{Sim}$

( ) Não

18. Tempo de empresa:

19. Área/Departamento:

20. Tipo de empresa:

( ) Familiar de caráter regional

( ) Familiar de caráter nacional

( ) Não familiar de caráter regional

( ) Não familiar de caráter nacional

( ) Multinacional

21. Porte da empresa:

22. Setor de atuação: 